\title{
Difficulties in the Preparation Process of High School Pass Entrance (LGS) and Their Reflections on Education in the Framework of Mathematics Teachers' Views
}

\author{
Mustafa Obay ${ }^{\mathrm{a}}$, Enes Demir ${ }^{\mathrm{b}}$ and Cahit Pesen \\ ${ }^{\text {a }}$ Siirt University, Education Faculty, Siirt/Turkey (ORCID: 0000-0002-2537-9438) \\ ${ }^{\mathbf{b}}$ Siirt University, Education Faculty, Siirt/Turkey (ORCID: 0000-0002-9012-8109) \\ ${ }^{\mathbf{c}}$ Siirt University, Education Faculty, Siirt/Turkey (ORCID: 0000-0001-9071-2770)
}

Article History: Received: 14 July 2020; Accepted: 2 January 2021; Published online: 5 February 2021

\begin{abstract}
Man tries to learn his surroundings by showing tendencies such as discovering, researching, asking questions, and noticing the relationships between objects. In other words, he tends to understand the world he lives in with various judgments. Therefore, it is important to raise individuals with advanced reasoning skills, mathematical thinking skills, proofing skills, problem solving skills, metacognitive knowledge, skills or qualifications. It can be said that this can only be possible with the right teaching models, methods, techniques and teachers who can use them in the most efficient way. In this context, the aim of the study is; To determine the difficulties in the preparation process for LGS, which has been implemented in our country since 2018, and the reflections of LGS on mathematics education applied in schools within the framework of the opinions of mathematics teachers and make suggestions accordingly. In the study, the screening model was adopted because it was tried to portray the thoughts of a certain group of participants on a subject. The sample of the study; It consists of 110 mathematics teachers who attended 8th grade classes in the 2018-2019 academic year. The data obtained from teachers' opinions were analyzed by content analysis method. According to this; The predominant opinion is that students have problems in understanding, interpreting, thinking and reasoning in the new examination system, however, because the textbooks and the exam are not parallel, teachers have various difficulties. In this direction, various activities can be organized to increase students' motivation and to gain reading habit. In addition, it is thought that it would be beneficial to provide teachers with in-service training for the exam.
\end{abstract}

Keywords: LGS, mathematics, teacher, difficulty

DOI:10.16949/turkbilmat.769347

Öz: Birey, doğumundan itibaren keşfetme, araştırma, sorular sorma, nesneler arasındaki ilişkileri fark etme gibi eğilimleri göstererek çevresini öğrenmeye çalışır. Başka bir deyişle çeşitli muhakemelerle yaşadığı dünyayı anlama eğilimdedir. Bundan dolayı muhakeme becerisi, matematiksel düşünme becerisi, ispat yapma becerisi, problem çözme becerisi, üst bilişsel bilgi, beceri veya nitelikleri gelişmiş bireylerin yetiştirilmesi önemlidir. Bu da ancak doğru öğretim modelleri, yöntemler, teknikler ve bunları en verimli şekilde kullanabilen öğretmenlerin varlığı ile mümkün olabileceği söylenebilir. Bu bağlamda çalışmanın amacı; ülkemizde 2018 yılından beri uygulanmaya başlanan LGS'ye hazırlık sürecinde yaşanan güçlükleri ve LGS'nin okullarda uygulanan matematik eğitimine yansımalarını matematik öğretmenlerinin görüşleri çerçevesinde tespit etmek ve bu doğrultuda önerilerde bulunmaktır. Çalışmada belli bir katılımcı grubunun bir konu üzerindeki düşüncelerini resmetmeye çalışıldığı için tarama modeli benimsenmiştir. Çalışmanın örneklemini; 2018-2019 eğitim öğretim y1lında 8 . Sınıflarda derse girmiş olan 110 matematik öğretmeninden oluşmaktadır. Öğretmen görüşlerinden elde edilen veriler içerik analizi yöntemiyle analiz edilmiştir. Buna göre; öğrencilerin yeni sınav sisteminde anlama, yorumlama, düşünme ve muhakeme etme sorunu yaşadığı bununla birlikte ders kitapları ile sınavın paralel olmadığı bu nedenle öğretmenlerin çeşitli zorluklar yaşadığı görüşü ağırlıktadır. Bu doğrultuda öğrencilerin motivasyonun artırılması ve okuma alışkanlığının kazanılmasını sağlamak için çeşitli etkinlikler yapılabilir. Ayrıca öğretmenlere de sınava yönelik hizmet içi eğitimlerinin verilmesinin yararlı olacağı düşünülmektedir.

Anahtar Kelimeler: LGS, matematik, öğretmen, güçlük

Türkçe sürüm için tıklayınız

\section{Introduction}

Human beings are a creature that can think differently from other living things and question both their own actions and their environment. With this feature, he tries to learn his surroundings by showing tendencies such as discovering, researching, asking questions, and noticing the relationships between objects. In other words, he tends to understand the world he lives in with various judgments. In this process, these judgments developed by the individual affect his life significantly as well as his education life deeply. In parallel with this, information and communication technologies have covered every stage of human life. (Kumandaş \& Kutlu, 2014; Tiemann, 2011) The temporal difference between generations has gradually narrowed. The world, lifestyle and social change seen by a child born in the nineties and a child born in the 2000s are quite different from each other. Therefore, education cannot be done with the methods, tools and teaching techniques of the nineties or earlier. This situation has caused changes in education and training programs in our country as well as throughout the

Corresponding Author: Enes Demir (D) email: enesdemir@siirt.edu.tr

Citation Information: Obay, M., Demir, E., \& Pesen, C. (2021). Difficulties in the preparation process of high school pass entrance (LGS) and their reflections on education in the framework of mathematics teachers' views. Turkish Journal of Computer and Mathematics Education, 12(1), 221-243. http://doi.org/10.16949/turkbilmat.769347 
world. Therefore, this situation has made a new perspective necessary in mathematics teaching. "New knowledge, opportunities and tools are reshaping our perspective on mathematics, our expectations from mathematics, the way we use mathematics, and above all our mathematical learning and teaching processes." (MEB, 2013). This new perspective has made it a priority target to raise individuals with advanced reasoning skills, mathematical thinking skills, proofing skills, problem solving skills, metacognitive knowledge, skills or qualifications. The realization of these goals can only be achieved with an education that is suitable for these skills. Goswami (2004) stated in his study that children obtained true or false conclusions and inferences by conducting inductive or deductive judgments in various aspects from the first years of their lives. NCTM (2000) also stated that children make very different judgments in primary education and in the following years, and they can make various inferences, right or wrong, according to their own assumptions. Therefore, it can be thought that the strategies developed by children at this age will be determinant in their future education lives. Because reasoning is one of the basic concepts at the center of teaching and learning mathematics, as in all areas of life (Russell, 1999). However, one of the concepts that opens the door to reasoning is to increase the understanding capacity of the learning individuals. For this purpose, special lectures or courses are given to increase understanding skills in developed western societies in the field of education such as the USA (Francisco \& Maher, 2005; Generazzo, 2011; Hiebert \& Grouws, 2007; Hsu, 2010; Lee, 1999; Martin \& McCrone, 2009; Pulley, 2010). Thus, in terms of conceptual continuity, concepts that form the basis of mathematics such as mathematical thinking, association, abstract thinking, intuition, and communication can only be acquired by teaching correct reasoning. It can be said that this can only be possible with the right teaching models, methods, techniques and teachers who can use them in the most efficient way.

Designing educational programs; It is important to determine appropriate models, methods and techniques in the realization of teaching. Shulman (1986) emphasized the importance of the relationship between pedagogical content knowledge and field knowledge, and drew attention to the technique used and its practitioner. In other words, teachers play an important role in addition to using appropriate teaching methods and techniques to overcome the difficulties encountered in mathematics teaching and to enable students to make correct judgments. Therefore, it is very important that teachers who contribute to the realization of teaching use appropriate teaching models, methods and techniques in this process. In this regard, teachers; It is of great importance for students to be aware of reasoning processes, to make instructional decisions in order for them to develop their reasoning with correct strategies and to minimize their mistakes (Güven \& Demir, 2015). Therefore, teachers who are at the center of teaching; Knowing the mathematical and mental thinking processes of students and giving them the necessary feedback for this requires them to be aware of possible reasoning errors (Petrou \& Goulding, 2011). This situation is directly related to the education teachers receive and therefore their knowledge of teaching mathematics. Because, if a teacher's understanding and infrastructure regarding the acquisitions and concepts to be taught is limited, it may prevent the teaching process from being carried out efficiently. Therefore, it can cause students to make many reasoning mistakes in the learning process or to continue their reasoning mistakes (Stylianides \& Stylianides, 2009). In this sense, teachers must first be equipped themselves in order to reveal students' skills such as reasoning, problem solving, abstraction, and proof (Baki, 2008). Otherwise, develop students' correct judgments; It may become more difficult for them to develop their skills in understanding, solving and interpreting mathematical problems (İskenderoğlu \& Baki, 2011).

Teachers' understanding of the basic components of modern mathematics teaching such as mathematical thinking, proof, reasoning and problem solving, the strategies they put forward and the methods they use have a great influence on the shaping of this process. In other words, if a teacher does not have sufficient knowledge to develop reasoning strategies and reasoning in the learning-teaching process, it cannot be expected that his students will gain this understanding or these skills. For this, it is important to know the understanding of teachers towards the teaching process of mathematics learning, the methods they use in this process, the strategies they put forward, or how they evaluate the process (Healy \& Hoyles, 2000). NCTM (2000) also reveals the importance of teachers in the process by stating that teachers' field knowledge and understanding, knowledge about students and teaching strategies contribute to the effectiveness of mathematics teaching. Therefore, it is important for teachers to know the reasoning they put forward while dealing with the problems that their students have solved, the problem-solving steps they have followed in this process, the reasons they have presented for these steps, to recognize the relationships between the stages and to evaluate them correctly. This situation reveals the importance of teacher training programs. Because it is important that the mathematics teaching process is carried out properly and the actions inherent in basic skills are kept alive, but the role of teachers in this process cannot be denied. In this process, teachers play an important role in helping students gain skills such as making sense of mathematical concepts and the relationships between these concepts, interpreting and associating them with other mathematical concepts and topics (Kinach, 2002; Vale, McAndrew \& Krishnan, 2011; NCTM, 2000; Van de Walle, 2013). Thus, it is thought that students who gain this skill will learn mathematics more meaningfully, value mathematics and permanent learning will be realized (Businskas, 2008; MEB, 2013). 


\subsection{Problem Statement}

Due to its nature, each individual is different. For this reason, the fact that the curriculum and the measurement and evaluation process are "suitable for everyone", "valid for everyone and standard" is not suitable for human nature. (MEB, 2018). From this point of view, it is necessary to include maximum diversity and flexibility in the measurement and evaluation process. This diversity; Since it significantly affects all dynamics such as individual, education level, course content, social environment, school facilities, it requires a serious change in the curriculum. This change in the curriculum; It has become the main target of most modern countries. For this reason, education - training programs are rearranged according to the needs of the age and in accordance with new changes. Because measurement and evaluation is the most important part of education and training (Dwyer, 1998). Both in order to evaluate the change made and for the countries that do not want to be behind the times with their education reforms to make a situation assessment; Various international exams or events are held regularly every year. One of the most important of these activities is PISA (Program for International Student Assessment). Our country has been involved in such practices in order not to be left behind in the information age, whose dynamics has changed in recent years, and includes appropriate regulations in education. In our country, which has a significant young population, it is necessary to determine how much students have acquired these skills as well as bringing new, practical and permanent solutions to the problems they face (Başol, 2016). For this purpose, PISA, TIMMS (Trends in International Mathematics and Science Study) and our ranking in similar international exams are considered. Both the content of such exams are not suitable for the teaching approach and assessment processes applied in our country, and the fact that our ranking in these exams is not at the desired level has made some changes necessary. For this purpose, our country's education programs and assessment and evaluation systems have been rearranged in order to raise individuals with skills such as research, questioning, problem solving, reasoning, understanding what they read, using technology effectively, reasoning and commenting. Changes have been made in assessment and evaluation in accordance with the standards of international exams. The first stage of this change; The type of examination introduced by the assessment and evaluation system in recent years is the centrally applied LGS (High School Pass Exam). This exam aims to prepare students for international examination standards and to ensure that qualifications can be made among students in transition to secondary education.

Considering the content of PISA, TIMMS and similar international exams, the following dimensions are considered as criteria for math questions in LGS. Student;

1. Will be able to develop and use mathematical literacy skills effectively.

2. Will be able to understand mathematical concepts and use these concepts in daily life.

3. Will be able to express their own thoughts and reasoning easily in the process of problem solving and see the deficiencies or gaps in the mathematical reasoning of others.

4. Will be able to use mathematical terminology and language correctly to explain and share mathematical thoughts in a logical way.

5. Will be able to make sense of the relationships between human and objects and the relations between objects by using the meaning and language of mathematics.

6. Will be able to develop his / her metacognitive knowledge and skills, and consciously manage his / her own learning processes.

7. Will be able to use anticipating and mental processing skills effectively. The main purpose in setting these criteria is; the students' reasoning, causal thinking, that is, the development of reasoning skills, to provide a deep understanding of learned mathematical concepts. (MEB, 2018)

\subsection{Purpose of the research}

With the effect of factors such as technology and communication, a continuous change and renewal steps are taken in education programs. As in all levels of education, new regulations are made in transition to secondary education. Therefore, each country has different practices in order to make screenings among students. While the USA, Japan, England, Hungary, South Korea and the Netherlands take students to high school with an exam, China, France, Italy and Singapore apply a secondary school graduation exam. In some countries, only school grades, teacher opinion, school-based entrance examination are also used as an effective method. In Turkey, secondary (high schools) students in the placement process Ministry of Education (MONE) is implemented by the central examinations is decisive. When we look at the applied central exams, since 2000, students have been placed in the High School Entrance Exam (LGS). Since 2004, Secondary Education Institutions Selection and Placement Exam (OKS) has been passed. Level Determination Exams (SBS) have been implemented since 2008. In 2014, the central examinations conducted within the scope of Transition from Basic Education to Secondary Education (TEOG) started to be implemented. With the abolition of TEOG in 2018, the High School Pass Exam (LGS) was started to be applied. MEB states the reasons for the transition to new examination systems as the renewals in the curriculum and the new systems will be more suitable for students. Central exams applied in various periods differ in method and content. For this reason, it is thought that the newly introduced types of 
exams cause various difficulties for students and teachers, and it is important to use appropriate resources and teaching approaches to overcome these difficulties. He is the planner and implementing teacher of the education and training process in schools. Teachers are the people who can best evaluate this process. Therefore, in order to increase the success of students in the Mathematics LGS exams, which have been applied in recent years, it is important to determine what difficulties students and teachers experience in this process and how the difficulties brought by the LGS exam affect teachers' understanding of mathematics education. In this context, the aim of the study is; To identify student-teacher difficulties in the preparation process for Mathematics LGS, which has been implemented in our country since 2018, and the reflections of LGS on mathematics education applied in schools within the framework of teachers' opinions and make suggestions accordingly.

\subsection{Research Problem}

The research is shaped around its main problem: "What are the difficulties in the preparation process of the Mathematics High School Pass Exam (LGS)? “ In this context, the sub-problems of the study were formed by asking various questions to the teachers.

\subsubsection{Sub-problems of the research}

1) What are the difficulties faced by students in solving LGS mathematics questions, teachers in preparing students for LGS mathematics exams, and what are the suggestions for overcoming these difficulties?

2) What are the differences between the features of the mathematics questions in the LGS, the suitability of the questions to the students' level and the exam questions for transfer to high schools in the previous semester?

3) What is the level of compatibility of the question types used in the exams of teachers in mathematics lessons with the LGS mathematics questions regarding how the LGS affects mathematics education?

Along with these sub-problems, it was tried to determine how to evaluate the proficiency of the source books used in mathematics lessons and the usefulness level of the LGS mathematics sample questions published by the Ministry of Education.

\section{Method}

In this study; we used the scanning model. because it will reveal the opinions of the participant group on a subject in line with a certain purpose. In this method, data can be collected through interviews, as well as by sending open-ended questions to participants and taking their written opinions. Collecting opinions in this way is considered as a questionnaire in some sources (Çepni, 2014). The collected data were analyzed by content analysis. About content analysis in the literature; The definition of "systematic explanation of phenomena in its simplest form" passes (Breakwell, Smith and Wright, 2012). Content analysis can be applied to data, information or evidence from a wide variety of contexts, including participatory and non-participant observation, interviews, archives, and non-experimental, experimental and quasi-experimental designs (Breakwell, Smith and Wright, 2012).

\subsection{Participants}

The sampling method used in this study is the "purposeful sampling method". Purposeful sampling; It means pre-considering and determining the sample in relation to a specific purpose or subject in focus (Punch, 2005). In this respect, the participants are middle school mathematics teachers in line with the purpose of the problem. Research participants, constitutes the second period 2018-2019 academic year from Turkey's Southeastern Anatolia Region working in secondary schools and 110 mathematics teachers who entered at least one period in the 8. classroom course. Some characteristics of the participants of the study are shown in Table 1.

Table 1. Characteristics of Participants

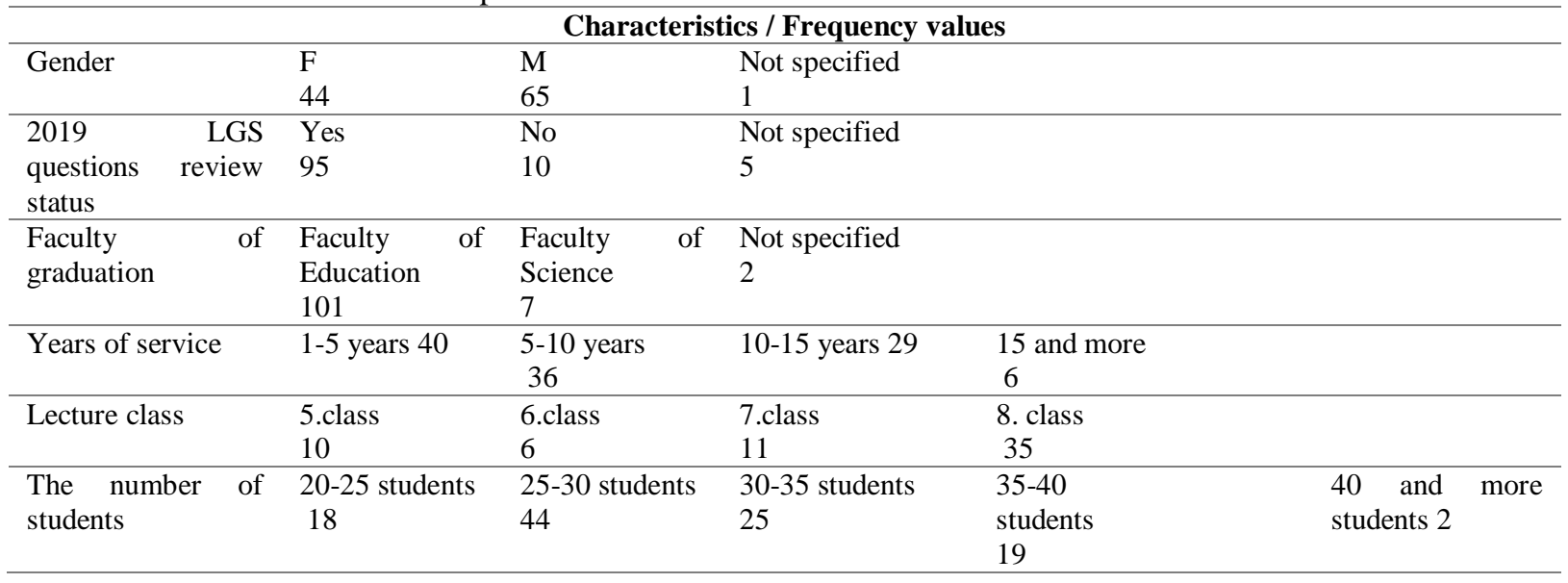




\subsection{Data Collection Tools}

In this study, a semi-structured opinion form prepared by the researchers was used as a data collection tool. In order to ensure the validity and reliability of the prepared form, separate pilot applications (each researcher applied the form to 10 different teachers) by three different researchers. The obtained data were analyzed and compared, and the final version of the interview form was formed. In this form, open-ended questions were asked to teachers and some of the problems experienced in LGS mathematics exams were tried to be described. The general scope of these questions is what difficulties teachers have in preparing students for the LGS exam and their suggestions for overcoming these difficulties. For this purpose, 15 open-ended questions were prepared. However, in the preliminary interviews with two academicians and 3 teachers, it was concluded that some of the questions prepared would produce similar or very similar answers. In this respect, eight of the repetitive questions were eliminated. Then, with the remaining questions, mathematics teachers in a middle school were visited again and they were asked to evaluate the prepared form. The results obtained were considered to have a sufficient basis for conducting this research, and this final form of the form was used for the research. Within the scope of this research, the participation of the teachers participating in the research was preferred on a voluntary basis and it was accepted that they gave sincere answers in this respect. However, it was observed that some teachers did not give sufficient answers or even did not answer some questions at all. These forms were excluded from the assessment on the basis of questions, but there were no interview forms that were excluded from assessment as a whole.

\subsection{Analysis of Data}

All interviews were recorded and transcribed in this study, which was conducted to determine what difficulties students and teachers experienced in this process and how the difficulties brought by the LGS exam affected teachers 'understanding of mathematics education in order to increase students' success in mathematics LGS exams. After the data were transcribed, they were subjected to content analysis, which is a qualitative data analysis technique. Analyzes for the obtained data were made together by different researchers ( 2 researchers analyzed the data and the third researcher compared the analyzes) and the disagreements about the coding were discussed until a common decision was reached. Themes related to these codings and sub-themes of these themes were determined. In line with the purpose of the study, it was analyzed and presented in detail with examples in the findings section.

\section{Findings}

For teachers and students, the textbook is the most important resource that can be used both to obtain lesson outcomes and to prepare students for exams. The compatibility of LGS questions with the questions in the mathematics textbook will contribute to students and teachers to use the textbook more intensely and willingly. The compatibility of the questions in the textbooks with the LGS questions will also reduce the need for supplementary textbooks. The following question was asked to the teachers in order to determine the teachers' views on this subject." Do you think you have used textbooks to train your students for the LGS math exam? Why is that?" The data obtained in this question are shown in Table 2.

Table 2. Teacher's Use of Textbooks in the Training of Students for the LGS Mathematics Exam

\begin{tabular}{|c|c|c|c|}
\hline \multirow{9}{*}{$\begin{array}{l}\text { Teacher's Answer } \\
\text { Yes }\end{array}$} & \multicolumn{2}{|c|}{ Using The Textbook } & \multirow{2}{*}{$\begin{array}{c}\text { Frequency } \\
4\end{array}$} \\
\hline & \multirow[t]{5}{*}{ Because } & $\begin{array}{l}\text { Providing diversity of questions and } \\
\text { curriculum compulsory }\end{array}$ & \\
\hline & & $\begin{array}{l}\text { Expectation of similar questions in } \\
\text { LGS }\end{array}$ & 16 \\
\hline & & Sufficient & 2 \\
\hline & & To learning outcome & 6 \\
\hline & & Provides education equality & 2 \\
\hline & \multirow[t]{3}{*}{ But } & I also use different sources & 5 \\
\hline & & Insufficient & 2 \\
\hline & & Insufficient for LGS & 3 \\
\hline \multirow{3}{*}{ No } & \multirow{3}{*}{ Because } & Insufficient for LGS & 3 \\
\hline & & Insufficient & 5 \\
\hline & & low level & 2 \\
\hline \multirow[t]{4}{*}{ Partially } & \multicolumn{2}{|c|}{ To learning outcome } & 4 \\
\hline & \multicolumn{2}{|c|}{ Insufficient number of questions } & 2 \\
\hline & \multicolumn{2}{|c|}{ Exam-oriented } & 2 \\
\hline & \multicolumn{2}{|c|}{ Question diversity and curriculum compulsory } & 4 \\
\hline
\end{tabular}


Considering the analysis of the data in Table 2, it is seen that a significant portion of the mathematics teachers (54\%) answered "Yes". It is seen that mostly "similar question expectation in LGS" is seen in the reasons why mathematics teachers related the yes answer causally. In addition, it is seen as an important justification that it is "oriented towards gains". Another important category appears to be "providing a variety of questions and curriculum obligation". It is seen that this category is related both to similar questions to be raised in LGS and to gains. In this case, it can be said that while teachers mostly benefit from textbooks, similar question expectation towards LGS and the obligation to comply with the curriculum stand out. For teachers who answered "partially", the categories for the outcomes and for the exam are seen in parallel with the answers of the teachers who answered "Yes". Another category is "question diversity and curriculum obligation". This is seen in the same category as teachers who answered "Yes". When the reasons of the teachers who answered "No" are classified, the answer "not sufficient for LGS" can be taken as basis. However, it is thought that it is important to state that the textbooks are at the "knowledge level", that is, at the conceptual level, albeit low in frequency.

The following question was asked to determine the levels and reasons why mathematics teachers benefited from supplementary textbooks to prepare their students for LGS exam: "Do you think you have used supplementary textbooks to train your students for the LGS math exam? Why is that?" The analysis of the answers given by mathematics teachers related to the topic were given in Table 3.

Table 3. Use of Supplementary Textbooks for LGS Mathematics Exam

\begin{tabular}{llcc} 
Teacher's Answer & Using The Textbook & Frequency \\
\hline Yes & Because & For different question styles & 26 \\
\cline { 3 - 3 } & & More useful & 4 \\
\cline { 3 - 3 } & & Textbooks insufficient & 18 \\
\cline { 3 - 3 } & & Similar to LGS questions & 2 \\
\cline { 2 - 3 } & & To complete the shortcomings of the students & 5 \\
\cline { 3 - 3 } & & For reinforcement purposes & 14 \\
\cline { 3 - 4 } & & For the exam & 3 \\
\hline No & I use textbooks and EBA & 1 \\
\hline Partially & For different question styles & 2 \\
\hline
\end{tabular}

Considering the analysis of the data in Table 3, we see that the dominant opinion is that teachers use auxiliary textbooks for the LGS exam. One of the most important reasons for this is that the helpful textbooks have different question styles. Another dominant category is that the textbooks are inadequate in terms of LGS. The answers given as "To complete the deficiencies of the students", which is another category, complement the other two categories given above. However, the category of "because it is for the exam" is seen to express a direct purpose outside of the textbooks for the curriculum. Only the category of "I use textbooks and EBA" stands out categorically in the "no" answers given by the teachers.

The following question was asked to teachers in order to determine the reasons for students' failure in solving LGS mathematics questions. "What kind of difficulties do you think your students might have had in solving LGS math questions?" The analysis of the answers given by mathematics teachers to the question is shown in Table 4.

Table 4. Difficulties Experienced by Your Students in Solving LGS Math Questions

\begin{tabular}{lc}
\hline Teacher's Answer & Rate \\
\hline Lack of understanding and interpretation & $52 / 107$ \\
\hline Insufficiency of the education received & $5 / 107$ \\
\hline Lack of understanding and interpretation + processing skills & $2 / 107$ \\
\hline Above students' level & $2 / 107$ \\
\hline Lack of understanding and interpreting + prejudices & $3 / 107$ \\
\hline Psychological factors & $4 / 107$ \\
\hline Time + lack of comprehension and interpretation & $13 / 107$ \\
\hline Time problem & $3 / 107$ \\
\hline Long questions & $5 / 107$ \\
\hline Long questions + bias & $3 / 107$ \\
\hline Other & $15 / 107$ \\
\hline
\end{tabular}

When analyzing the data in Table 4, the category of "lack of understanding and interpretation" is seen predominantly. Generally, the detection frequency is 76. In addition, "duration" is seen as an important problem. 
The general incidence of the duration category is 16 . When other categories are considered, long questions are seen as an important problem. Similarly, bias (difficult bias of questions) is 11. When all these categories are considered, it can be said that there are some phenomena accompanying the general understanding and interpretation skill.

The question asked to determine how teachers evaluated the difference between mathematics teachers' central exams and LGS exams in previous years and how this difference affected mathematics education was "What kind of questions between the exam questions for transfer to high schools in the past period and the questions in 2017-2018 and 2018-2019? Do you see the differences? How do you think these differences affect or will affect the education you are doing? " has been in the form. The analysis of the answers given by mathematics teachers to this question is as shown in Table 5.

Table 5. Differences Between Previous Central Exams and LGS Exams, and Findings Regarding the Effect of This Difference on Mathematics Education

\begin{tabular}{|c|c|c|c|}
\hline Other Exams (Before LGS) & Frequency & LGS & Frequency \\
\hline \multirow{4}{*}{$\begin{array}{l}\text { Just based on the information and } \\
\text { operation }\end{array}$} & \multirow[t]{4}{*}{32} & Understanding and interpreting & 24 \\
\hline & & Analysis-synthesis level & 8 \\
\hline & & Using information skills & 2 \\
\hline & & $\begin{array}{l}\text { A balance is achieved in question } \\
\text { qualities } \\
\text { (More suitable for student level) }\end{array}$ & 21 \\
\hline \multirow[t]{2}{*}{ It motivated all students } & \multirow[t]{2}{*}{2} & $\begin{array}{l}\text { It only motivates successful } \\
\text { students }\end{array}$ & 2 \\
\hline & & Top-level skills & 5 \\
\hline TEOG questions were better & 3 & More difficult questions & 11 \\
\hline \multirow{3}{*}{$\begin{array}{l}\text { It was suitable for student level and } \\
\text { curriculum }\end{array}$} & \multirow[t]{3}{*}{4} & & \\
\hline & & Understanding and interpretation & 2 \\
\hline & & Students gain familiarity & 5 \\
\hline \multirow[t]{2}{*}{ Previous questions are easy } & \multirow[t]{2}{*}{5} & More difficult questions & 3 \\
\hline & & Distinctive & 2 \\
\hline
\end{tabular}

Considering the findings in Table 5, it is possible to evaluate teachers' opinions about the previous semester exams as positive and negative opinions. In the previous central exam evaluations, it is seen that the expressions "LGS requires understanding and interpretation", "analysis-synthesis" "requires the ability to use knowledge", in contrast to the statement that it was based only on information and processing. It is seen that the evaluation regarding this difference is mostly positive and there are statements showing that teachers need to change / renew themselves. However, negative opinions are also encountered. Among these, it is possible to see the views that "affected education and motivation negatively", "negatively affect self-confidence", "does not appeal to all students".

Within the scope of this research, another question asked in order to determine the difficulties experienced by mathematics teachers in preparing students for LGS mathematics exams;

A question was asked, "What kind of difficulties do you think you have while raising your students for LGS mathematics exams?" The analysis of the answers given by mathematics teachers to this question is shown in Table 6.

Table 6. Findings Regarding the Difficulties Encountered in Raising Students for LGS Mathematics Exams

\begin{tabular}{|c|c|c|c|}
\hline Problem Encountered & Frequency & Associated Result & Frequency \\
\hline Lack of thinking seen in students & 5 & Difficulty understanding & 2 \\
\hline \multirow[t]{2}{*}{ Problems caused by rote learning } & \multirow[t]{2}{*}{7} & $\begin{array}{l}\text { The problem of thinking } \\
\text { deficiency seen in students }\end{array}$ & 3 \\
\hline & & $\begin{array}{l}\text { Teachers are not ready for } \\
\text { the process }\end{array}$ & 2 \\
\hline \multirow[t]{2}{*}{ Insufficient reading habits } & \multirow[t]{2}{*}{6} & Difficulty understanding & 2 \\
\hline & & $\begin{array}{l}\text { Their ability to comment } \\
\text { remains low }\end{array}$ & 3 \\
\hline \multirow[t]{2}{*}{ LGS containing high level questions } & \multirow[t]{2}{*}{13} & Difficulty understanding & 4 \\
\hline & & $\begin{array}{l}\text { Dealing with these } \\
\text { problems is a problem in } \\
\text { terms of time and } \\
\text { efficiency }\end{array}$ & 4 \\
\hline
\end{tabular}


Table 6 continued

\begin{tabular}{|c|c|c|c|}
\hline $\begin{array}{l}\text { Conflict of curriculum and exam } \\
\text { questions }\end{array}$ & 11 & $\begin{array}{l}\text { Students are not interested } \\
\text { in the exam }\end{array}$ & 5 \\
\hline
\end{tabular}

The problem of not reaching enough questions

\begin{tabular}{llll}
\hline \begin{tabular}{l} 
Problematic knowledge infrastructure $\begin{array}{l}\text { Motivation problem } \\
\text { of students }\end{array}$ \\
\cline { 2 - 4 }
\end{tabular} & $\begin{array}{l}\text { Problems in reaching the } \\
\text { general public }\end{array}$ & 4 \\
\cline { 2 - 4 } & $\begin{array}{l}\text { Dealing with these } \\
\text { problems is a Problem in } \\
\text { terms of time and } \\
\text { efficiency }\end{array}$ & 2 \\
\hline Prejudice against mathematics & 1 & Motivation & 2 \\
\hline $\begin{array}{l}\text { Exam expectation and curriculum } \\
\text { mismatch }\end{array}$ & 2 & Motivation & 2 \\
\hline Lack of self-confidence in students & 2 & Difficulty understanding & 2 \\
\hline Lack of problem solving strategies & 6 & Difficulty understanding & 3 \\
\hline The problem of not finding enough & 4 & & \\
\hline
\end{tabular}
resources

Considering Table 6, when the answers given by the Mathematics teachers to the question "What kind of difficulties do you have while raising your students to the LGS mathematics exams" are examined, the most encountered problem is the "students' knowledge infrastructure is problematic" category. The related results put forward in relation to this category include problems such as "the motivation problem seen in students", "the problem of not reaching the entire population of students in the classroom", "limited time to obtain sufficient efficiency in mathematics lessons". Similarly, the thought "LGS contains high-level questions" is seen predominantly in teachers' expressions. In the related results, it is seen that students "have difficulty understanding" and create "problems in terms of time and efficiency". When the results related to the problems encountered are considered, it is seen that especially students experience "difficulty in understanding" and close to this "motivation problem".

Another question asked to mathematics teachers was "Do you think that the sample questions published by the Ministry of National Education regarding the questions that may occur in LGS mathematics exams are sufficient to have information about the exam? "There was a question in the form. With this question, it is aimed to determine the following issues;

The information obtained about question types will also be useful for textbooks and supplementary textbooks to be prepared by book authors. MoNE publishes sample questions regarding the types of questions that can be encountered in the LGS mathematics exams, which have been implemented for this purpose. It is tried to determine whether the questions asked to teachers and the sample questions published by the Ministry of National Education provide sufficient information about the exam questions to the students and teachers. The analysis of the answers given by mathematics teachers to this question is shown in Table 7.

Tablo 7. The Findings Regarding Whether Sample Questions Provide Sufficient Information About LGS

\begin{tabular}{|c|c|c|c|c|c|}
\hline $\begin{array}{l}\text { Qualification } \\
\text { status }\end{array}$ & Frequency & Quality & Frequency & Cause opinions & Frequency \\
\hline \multirow[t]{4}{*}{ Sufficient } & \multirow[t]{4}{*}{65} & \multirow[t]{3}{*}{$\begin{array}{l}\text { Tips for the } \\
\text { exam }\end{array}$} & \multirow[t]{3}{*}{16} & $\begin{array}{l}\text { The number of questions should } \\
\text { be increased }\end{array}$ & 6 \\
\hline & & & & Helpful & 2 \\
\hline & & & & Parallel with LGS & 5 \\
\hline & & $\begin{array}{l}\text { Questions are } \\
\text { sufficient }\end{array}$ & 52 & Parallel with LGS & 23 \\
\hline \multirow[t]{3}{*}{ Not enough } & \multirow[t]{3}{*}{18} & & & $\begin{array}{l}\text { The number of questions should } \\
\text { be increased }\end{array}$ & 5 \\
\hline & & & & Useful & 10 \\
\hline & & & & Simpler & 3 \\
\hline \multirow[t]{4}{*}{ Partially (11) } & \multirow[t]{4}{*}{11} & & & $\begin{array}{l}\text { The number of questions should } \\
\text { be increased }\end{array}$ & 1 \\
\hline & & & & However useful & 2 \\
\hline & & & & Simpler & 3 \\
\hline & & & & Parallel with LGS & 4 \\
\hline
\end{tabular}


When the findings in Table 7 were examined, the teachers stated that the sample questions for the exam were "sufficient" to have information about the exam. The teachers stated that the number of questions, which are stated to be a clue for the exam, should be increased and that such applications are beneficial. In the category of "not enough", when the opinions about the reason were examined, it was argued that "the questions of the Ministry of National Education are simpler than the LGS", "the number of questions should be increased." It is observed that the answers seen in the partial category mostly converge to the "not sufficient" category.

Mathematics teachers' opinions about what should be done in preparing students for LGS-type exams and higher education are of great importance. For this purpose, the following question has been posed. "What are your suggestions for students to achieve a higher level in the current situation?". The answers given by mathematics teachers regarding this question are as shown in Figure 1. In the creation of the data in Figure 1, unidirectional and bidirectional arrows were used for placing close to the center, color tone darkness and associated concepts depending on frequency frequencies.

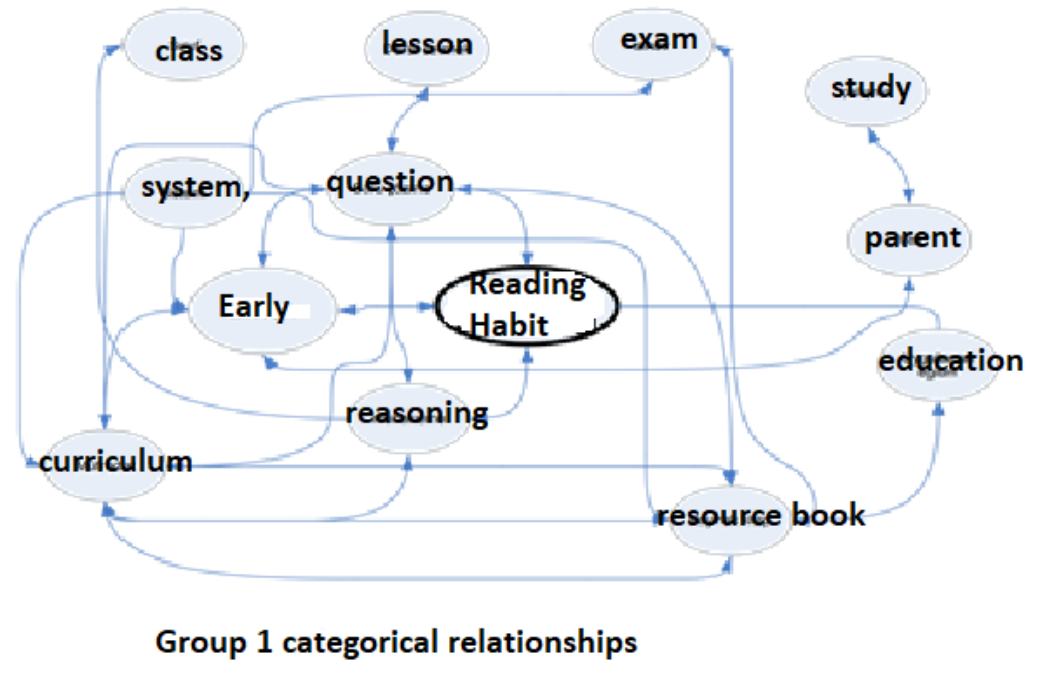

Figure 1. Main Categories in Relationship Chart and Relationships between Them

Figure 1 shows the main categories and the relationships between them. According to the analysis, the highest frequency was seen in the "reading habit" frequency (23). Second, the most frequently repeated frequency (21) is related to the expression "early". "Early" expression is the assessment that there should be a preparation that should start from previous classes. However, another category to be considered here is the "reasoning" category. Although its frequency is lower (10) compared to the others, the number of other categories it is associated with is more. Apart from this, another category, question solving (11), is also seen to have important links. The second-level category with which these categories are directly related was "motivation". Figure 2 shows the related network of relationships. Accordingly, the habit of reading should be used to eliminate prejudice. There are opinions that endearing the lesson can also remove prejudice.

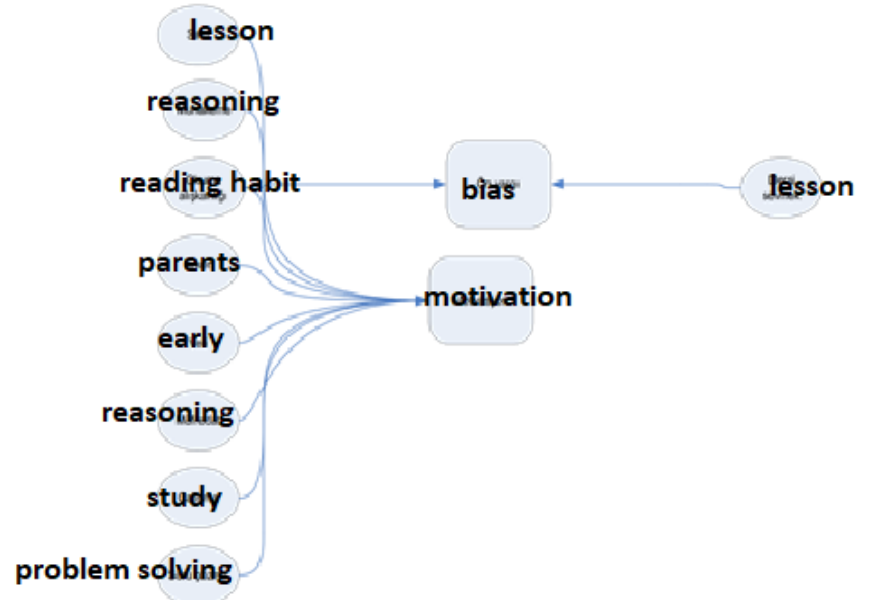

2. Group: Categorical links related to motivation.

Figure 2. Main Categories in Relationship Chart and Relationships between Them 


\section{Discussion and Conclusion}

The purpose of the study is to identify student-teacher difficulties in the preparation process for mathematics LGS and the reflections of LGS on mathematics education applied in schools within the framework of teachers' opinions and make suggestions accordingly. For this purpose, the data were analyzed in depth and in detail in the findings using content analysis technique. When the obtained findings are evaluated as a whole, it is seen that the most common problem seen in this study is the problem of understanding and interpretation. There can be many reasons for this. However, it can be said that in general, mathematics teachers set their goals directly for the exam. This situation brings along some important problems. For example, it can cause students to miss the stages of mental development or not to pay attention to their learning styles. Similar results have been found in studies in the literature. (Francisco and Maher, 2005; Generazzo, 2011)

One of the important results that emerged in the findings; It is observed that mathematics teachers think that the MEB textbooks are insufficient to meet the needs for the LGS exam. As a result, it can be stated that MEB textbooks are oriented towards structuring knowledge, but the LGS exam requires skills such as critical thinking, understanding and interpretation, and problem solving, which are mostly a set of high-level skills. Considering the analysis of the data as a whole, it can be seen that the purpose of MEB textbooks to have LGS content is limited. Because textbooks must primarily appeal to the general student population. However, in this context, it is understood that the LGS exam should be distinctive in terms of measurement and evaluation. However, in this case, it is thought that students preparing for the LGS exam are inevitable to benefit from the auxiliary textbooks in preparing for the LGS exam. This situation can be clearly seen in the findings discussed above, and it is stated that LGS questions require high-level skills of processing / associating information, reasoning, critical thinking (Table 5, Table 7) and these skills are more than just conceptual knowledge.

In line with the purpose of the study, "Do you think you have benefited from supplementary textbooks to train your students for the LGS mathematics exam? Why is that?" When the findings regarding the question are considered, it is seen that they mostly answered "Yes". When evaluated from a general point of view, it seems consistent with their answers to the use of textbooks. Accordingly, it is possible to say that the participants have a positive approach towards supplementary textbooks. In this respect, it is seen that teachers who are in an effort to prepare students for the LGS exam generally use the supplementary textbooks both on the basis of questions and as an auxiliary resource to complete the deficiencies of the students. Obtaining information from various sources cannot be a wrong behavior when considered essentially. However, not making it compulsory for students is important in terms of equality in education. Hiebert and Grouws (2007) emphasize a similar result in their study.

Secondary school math teachers said, "What kind of difficulties do you think your students might have had in solving LGS math questions?" When their answers to the question such as "Understanding and Interpretation" are analyzed, the general majority stands out as a "understanding and interpretation" problem. On the other hand, it is seen that the "time problem" is actually related to the speed of understanding and interpretation. Likewise, the concept of "long questions" seen here is not that students will be able to solve quickly, but rather problems that arise due to remembering and comprehending the problem as a whole. The development of the "reading habit" of the students who emerged in different parts of this study is considered as a measure for the development of these skills. Another phenomenon is the prejudice seen in students against mathematics and mathematical problems. Since this is a phenomenon that distracts the student from trying to understand at the beginning, it is a situation that should be especially considered. For researchers, the problem of understanding is that it is more related to association and reasoning. As a second explanation, there may be a problem arising from information classification. This is the knowledge of what things are, that is, knowledge of recognition and how things are done (Pears, 2004). Accordingly, the type of information that the student focuses on is considered to be important. It suggests that students who have gone through an enlightening process in which it is mostly memorized how it is done can answer questions that require such an operation, but fail in problems that require association and reasoning. This leads to the conclusion that an education arrangement should be made to improve students' especially reasoning skills.

Secondary school mathematics teachers' "What kind of differences do you see between the exam questions for the transition to high schools in the past and the questions in 2017-2018 and 2018-2019? How do you think these differences affect or will affect the education you are doing? " Considering the analysis of their answers to the question, it is seen that the expression "Based on information and processing only" stands out in relation to previous years. This situation seems consistent with the association and reasoning explanation stated above. The fact that the LGS exam questions are mostly at "Understanding and Interpretation" and "Analysis-Synthesis level" suggests that this is a valid explanation for this situation. According to the evaluation of middle school mathematics teachers, it is possible to say that they consider this situation important in terms of the discrimination of high-level skills. In addition, the presence of the "discriminating", ie selective answer obtained from the findings shows that teachers have similar thoughts on this issue. 
Considering the findings for the question of "What kind of difficulties do you have while raising your students for the LGS mathematics exams" question directed to the participants, it is seen that the "students' knowledge infrastructure is problematic" category is dominant and this leads to various problems. Individuals with a problematic knowledge infrastructure will not be able to make connections at a sufficient level, so they will have difficulty in realizing the desired level of thinking and understanding. Similarly, "motivation problem" is an important factor for students to continue their education. Another noticeable category in the findings of this question is that "LGS contains high level questions". Again, this is a situation that can be directly or indirectly associated with the knowledge infrastructure of the students. Is it because the level of student knowledge is insufficient or is it because the LGS includes high level questions? It appears to be an important problematic. When the expressions of the teachers are analyzed, the "difficulty in understanding" the students explained in the "related result" classification stands out. Again, one of the results obtained in this study is the explanation that students do not generally have reading habits and this causes comprehension problems in students.

In terms of this research, it is thought that the category of "Problems caused by rote learning" is important among the findings of this question. Accordingly, the problem of "thinking deficiency seen in students" is an important problem. In essence, the problem of reasoning seen in different parts of this research is named by another name. When all these are combined, it can be said that students who have difficulty in understanding have problems with thinking or reasoning and this leads to very important problems.

Asked to the participants, "Do you think that the sample questions published by the Ministry of National Education regarding the questions that may arise in the LGS mathematics exams are sufficient to have information about the exam?" Considering the findings of the question in the form of, it is mostly that the questions published by the Ministry of National Education are sufficient, but the number of questions should be increased. In addition, as stated above, it is the opinion that such questions should be placed in the reference book and lead to a design that can address different levels.

Addressed to mathematics teachers, "What are your suggestions for students to achieve a higher level?" Considering the first cycle schematic analysis of their answers to the question (Figure 1), a significant proportion of teachers emphasized the inadequacy of students' reading habits. The conviction that reading habits will affect students' comprehension levels is consistent with his answers to previous questions. In addition, it was stated that the reading habit affects the reasoning skills and problem solving habits that are close to him. This determination of teachers is also similar to the literature (Kilpatrick, 2001). However, another fact that is as important as this is that exposing the mathematics teachers to some training in the early age or classroom periods of the students will increase the success and student development. Among these, training such as reading habits, parent responsibility, and problem solving practices can increase student success. Related to this, when Figure 1 is examined, it is seen that there are various cycles. One of these cycles is early education, reading habits, practical training, resource book, curriculum cycle and it is seen that it is a process that affects each other. Another cycle that is considered important for researchers is the reading habit, reasoning, curriculum, and question solving cycle. They think that this cycle may affect students' success. Because it is known that reasoning is important in every stage of understanding and relating reading.

In this study, taking into account the opinions expressed by mathematics teachers on student achievement, a second cycle analysis was required. This coding and analysis is as shown in Figure 2. Accordingly, it can be said that motivation is a very important factor in student success. Although it is known that motivation alone is not sufficient for success in terms of learning psychology (Howe, 2001), it is accepted that it has an important effect in terms of continuity in the learning process. In this respect, it can be said that motivation, in other words, student willingness plays a determining role. As some teachers stated this in the first cycle analysis, the opinion that the student-family relationship plays an important role is considered important. Another phenomenon that is seen and cared about in Figure 2 is the relationship between reading and prejudice. The relationship seen here is basically an opposite one. There is a belief that as the reading habit develops, prejudice will decrease and love of the lesson will emerge. In this respect, it can be said that the reading habit has an important place in teachers' evaluations and that this habit is important for preparing students for the future.

\section{Recommendations}

Based on the data obtained as a result of the study, it is seen that the students have problems in the fieldspecific skills such as understanding, interpretation, thinking and reasoning in the new examination system. On the other hand, the opinion is that the textbooks and the exam are not parallel, so teachers have various difficulties. In this direction, various activities can be organized to increase students' motivation and to gain reading habit. By making use of constructivist teaching methods and techniques, learning environments where students can construct knowledge can be designed and studies can be done accordingly. In addition, it is thought that it would be beneficial to provide teachers with in-service training for the exam. 


\section{Matematik Öğretmenlerinin Görüşleri Çerçevesinde Lise Geçiş Sınavının (LGS) Hazırlık Sürecindeki Güçlükler ve Eğitime Yansımaları}

\section{Giriş}

İnsanoğlu diğer canlılardan farklı olarak düşünebilen, hem kendi eylemlerini hem de çevresini sorgulayabilen bir varlıktır. Bu özelliğiyle doğumundan itibaren keşfetme, araştırma, sorular sorma, nesneler arasındaki ilişkileri fark etme gibi eğilimleri göstererek çevresini öğrenmeye çalışır. Başka bir deyişle çeşitli muhakemelerle yaşadığı dünyayı anlama eğilimdedir. Bu süreçte bireyin geliştirdiği bu muhakemeler yaşamını önemli derecede etkilediği gibi eğitim öğretim hayatını da derinden etkileyebilmektedir. Buna paralel olarak bilgi ve iletişim teknolojileri insan hayatının her evresini kaplamış durumdadır.( Kumandaş \& Kutlu, 2014; Tiemann, 2011) Kuşaklar arası zamansal fark giderek daralmıştır. Doksanlarda doğan bir çocukla iki binli yıllarda doğan bir çocuğun gördüğü dünya, yaşam tarzı, toplumsal değişim birbirinden oldukça farklıdır. Bundan dolayı artık doksanlar ya da daha önceki dönemlerin yöntemleri, araçları ve öğretim teknikleriyle eğitim-öğretim yapılamaz. $\mathrm{Bu}$ durum dünya genelinde olduğu gibi bizim ülkemizde de eğitim-öğretim programlarının değişmesine sebep olmuştur. Dolayısıyla bu durum matematik öğretiminde de yeni bir bakış açısını zorunlu hale getirmiştir. "Yeni bilgiler, firsatlar ve araçlar matematiğe bakış açımızı, matematikten beklentilerimizi, matematiği kullanma biçimimizi ve hepsinden önemlisi matematik öğrenme ve öğretme süreçlerimizi yeniden şekillendirmektedir." (MEB, 2013). Bu yeni bakış açısı muhakeme becerisi, matematiksel düşünme becerisi, ispat yapma becerisi, problem çözme becerisi, üst bilişsel bilgi, beceri veya nitelikleri gelişmiş bireylerin yetiştirilmesini öncelikli bir hedef haline getirmiştir. Bu hedeflerin gerçekleşmesi ancak bu becerilere uygun bir eğitim-öğretim ile gerçekleşir. Goswami (2004) yaptığı çalışmada çocukların yaşamlarının ilk yıllarından itibaren çeşitli açılardan tümevarım veya tümdengelime dayalı muhakemeler yürüterek doğru ya da yanlış sonuçlar, çıkarımlar elde ettiğini belirtmiştir. NCTM (2000) de çocukların ilköğretimde ve takip edilen yıllarda çok farklı muhakemeler yürüttüklerini ve kendi varsayımlarına göre doğru ya da yanlış çeşitli çıkarımlar yapabildiklerini ifade etmiştir. Dolayısıyla çocukların bu yaşta geliştirdikleri stratejiler ilerideki eğitim hayatlarında belirleyici olacağı düşünülebilir. Çünkü muhakeme, yaşamın her alanında olduğu gibi matematik öğretme ve öğrenmenin de merkezinde yer alan temel kavramlardan biridir. Bununla beraber muhakemeye kapı aralayan kavramlardan biri öğrenen bireylerin anlama kapasitelerinin artırılmasıdır. Bu amaçla özellikle ABD gibi eğitim alanında gelişmiş̧ bat1 toplumlarında anlama becerisini artırma ile ilgili özel dersler veya kurslar verilmektedir. (Francisco ve Maher, 2005; Generazzo, 2011; Hiebert ve Grouws, 2007; Hsu, 2010; Lee, 1999; Martin ve McCrone, 2009; Pulley, 2010). Böylece kavramsal bir süreklilik açısından matematiksel düşünme, ilişkilendirme, soyut düşünme, sezgi ve iletişim gibi matematiğin temelini oluşturan kavramlar ancak doğru bir muhakemede bulunmayı öğreterek kazandırılabilir. Bu da ancak doğru öğretim modelleri, yöntemler, teknikler ve bunları en verimli şekilde kullanabilen öğretmenlerin varlığı ile mümkün olabileceği söylenebilir.

Eğitim-öğretim programları tasarlanırken; öğretimin gerçekleşmesinde uygun model, yöntem ve tekniklerin belirlenmesi önem arz etmektedir. Shulman (1986) pedagojik alan bilgisi ile alan bilgisi arasındaki ilişkinin önemine vurgu yaparak kullanılan teknik ve uygulayıcısına dikkat çekmiştir. Başka bir deyişle matematik öğretiminde karşılaşılan güçlüklerin üstesinden gelmek ve öğrencilerin doğru muhakemeler yürütmelerini sağlamak için uygun öğretim yöntem ve tekniklerin kullanmasının yanında öğretmenler de önemli rol oynamaktadır. Dolayısıyla öğretimin gerçekleşmesine katkıda bulunan öğretmenlerin bu süreçte uygun öğretim model, yöntem ve teknikleri kullanmaları oldukça önemlidir. Bu bakımdan öğretmenlerin; öğrencilerinin muhakeme süreçlerinin farkında olmaları, onların doğru stratejilerle muhakemelerini geliştirmelerini ve muhakeme hatalarını en aza indirmeleri için öğretimsel kararlar alabilmesi büyük önem taşımaktadır (Güven ve Demir, 2015). Dolayısıyla öğretimin merkezinde yer alan öğretmenlerin; öğrencilerin matematiksel ve zihinsel düşünme süreçlerini bilme ve buna yönelik onlara gerekli dönütler verme, onların olası akıl yürütme hatalarının farkında olmaları gerektirmektedir (Petreu ve Goulding, 2011). Bu durum öğretmenlerin aldığı eğitim ve dolayısıyla sahip oldukları matematiği öğretme bilgisi ile doğrudan ilişkilidir. Çünkü bir öğretmenin öğreteceği kazanım ve kavramlara yönelik anlayışı ve alt yapısı sınırlı ise öğretme sürecinin verimli bir şekilde yürütülmesini engelleyebilmektedir. Bundan dolayı öğrencilerinin öğrenme sürecinde birçok muhakeme hatası yapmalarına ya da sahip oldukları muhakeme hatalarının devam etmelerine sebep olabilmektedir (Stylianides ve Stylianides, 2009). Bu anlamda öğretmenlerin, öğrencilerin sahip olduğu muhakeme, problem çözme, soyutlama ve ispat yapma gibi becerilerini ortaya çıarabilmesi için öncelikle kendilerinin donanımlı olması gerekmektedir (Baki, 2008). Aksi takdirde öğrencilerini doğru muhakemeler geliştirme; matematiksel problemleri anlama, çözme ve yorumlama açısından becerilerini geliştirmeleri daha da zorlaşabilir (İskenderoğlu ve Baki, 2011).

Öğretmenlerin matematiksel düşünme, ispat, muhakeme, problem çözme gibi çağdaş matematik öğretiminin temel bileşenlerine yönelik sahip olduğu anlayışlar, ileri sürdükleri stratejiler, kullandıkları yöntemlerin bu sürecin şekillenmesinde etkisi büyüktür. Başka bir deyişle bir öğretmenin öğrenme - öğretme sürecinde akıl yürütme stratejileri ve muhakeme geliştirmeye yönelik yeterli düzeyde bir bilgiye sahip olmaması durumunda öğrencilerine de bu anlayışı ya da bu becerileri kazandırması beklenemez. Bunun için öğretmenlerin matematik 
öğrenme öğretme sürecine yönelik anlayışlarının, bu süreçte kullandıkları yöntemlerinin, ileri sürdükleri stratejilerinin ya da süreci nasıl değerlendirdiklerinin bilinmesi önemlidir (Healy ve Hoyles, 2000). NCTM (2000) de öğretmenlerin sahip oldukları alan bilgisi ve anlayışları, öğrenciler hakkındaki bilgileri ve öğretim stratejilerinin matematik öğretiminin etkili olmasına katkıda bulunduklarından belirterek öğretmenin süreç içindeki önemini ortaya koymaktadır. Dolayısıyla öğretmenlerin, öğrencilerinin çözdükleri problemleri ele alırken onların ileri sürdükleri muhakemeleri, bu süreçte izledikleri problem çözme adımlarını, bu adımlarına yönelik sundukları gerekçeleri bilmeleri, aşamalar arasında ilişkileri fark etmeleri ve bunları doğru bir şekilde değerlendirmeleri önemlidir. Bu durum öğretmen yetiştirme programlarının da önemini ortaya koymaktadır. Çünkü matematik öğretme sürecinin elverişli bir şekilde gerçekleşmesi ve temel becerilerin doğasında yer alan eylemlerin bireylere yaşatılması önemli olmakla birlikte öğretmenlerin bu süreç üzerindeki rolü yadsınamaz. Bu süreçte öğretmenler, öğrencilerin matematiksel kavramları ve bu kavramlar arasındaki ilişkileri anlamlandırabilme, yorumlayabilme başka matematiksel kavram ve konularla ilişkilendirebilme gibi becerileri kazanmalarında önemli rol üstlenirler.( Kinach, 2002; Vale, McAndrew ve Krishnan, 2011; NCTM, 2000; Van de Walle, 2013). Böylece bu beceriyi kazanan öğrencilerin matematiği daha anlamlı öğrenecekleri, matematiğe değer verecekleri ve kalıcı öğrenmenin gerçekleşeceği düşünülmektedir.(MEB, 2013; Businskas, 2008).

\subsection{Problem Durumu}

Doğası gereği her bir birey farklıdır. Bu nedenle öğretim programlarının ve buna bağlı olarak ölçme ve değerlendirme sürecinin "herkese uygun", "herkes için geçerli ve standart olması" insanın fitratına uygun değildir. (MEB, 2018). Bu durumdan hareketle ölçme ve değerlendirme sürecinde azami çeşitlilik ve esnekliğe yer vermek gerekmektedir. Bu çeşitlilik; birey, eğitim düzeyi, ders içeriği, sosyal ortam, okul imkânları gibi bütün dinamikleri önemli ölçüde etkilediği için öğretim programlarında da ciddi bir değişimi gerektirmektedir. Öğretim programlarındaki bu değişim; çağdaş ülkelerin çoğunun temel hedefi haline gelmiştir. Bu sebeple eğitim - öğretim programları çağın ihtiyaçlarına göre ve yeni değişimlere uygun şekilde tekrar düzenlenmektedir. Çünkü ölçme ve değerlendirme, eğitim ve öğretimin en önemli parçasıdır. Hem yapılan değişimi değerlendirmek amacıyla hem de eğitim reformlarıyla çağın gerisinde kalmak istemeyen ülkelerin durum tespiti yapmaları için; her yıl düzenli olarak uluslararası çeşitli sınavlar ya da etkinlikler gerçekleştirilmektedir. Bu etkinliklerden önemli olanlardan biri PISA (Programme for International Student Assessment) dır. Ülkemiz de son yıllarda dinamikleri değişen bilgi çağında dünyadan geride kalmamak için bu tür uygulamalara dahil olmakta ve eğitimde buna uygun düzenlemelere yer vermektedir. Önemli bir genç nufus kitlesine sahip olan ülkemizde öğrencilerin karşılaştıkları problemlere yeni, pratik ve kalıcı çözümleri kazandırmakla beraber bu becerileri ne kadar kazandıklarının belirlenmesi de eğitimin çıktılarını değerlendirmek açısından gereklidir (Başol, 2016). Bunun için son yıllardaki PISA, TIMMS (Trends in International Mathematics and Science Study) ve benzeri uluslararası sınavlardaki sıralamamız göz önüne alınarak değerlendirilmektedir. Gerek bu tarz sınav içeriklerinin ülkemizde uygulanan öğretim yaklaşımına ve ölçme değerlendirme süreçlerine uygun olmaması gerek bu sınavlardaki sırlamamızın istenilen seviyede olmaması bazı değişikliklerin yapılmasını zorunlu hale getirmiştir. Bunun için araştırma, sorgulama, problem çözme, akıl yürütme, okuduğunu anlama, teknolojiyi etkin kullanma, muhakeme ve yorum yapabilme gibi becerilere sahip bireyler yetiştirmek için ülkemizin eğitim programları ve ölçme değerlendirme sistemleri yeniden düzenlenmiş̧tir. Uluslararası yapılan sınavların standartlarına uygun ölçme değerlendirmede değişiklikler yapılmıştır. Bu değişikliğin ilk aşaması; ölçme ve değerlendirme sisteminin son yıllarda getirdiği sınav çeşidi merkezi olarak uygulanan LGS(Lise Geçiş Sınavı)'dir. Bu sınav, hem uluslararası sınav standartlarına öğrencileri hazırlama hem de ortaöğretime geçişte öğrenciler arasında elemelerin yapılabilmesini sağlama amacını gütmektedir.

PISA, TIMMS ve benzeri uluslararası sınavların içeriği göz önüne alınarak LGS'de çıkan matematik soruları için aşağıdaki ölçüler kriter olarak ele alınmıştır. Öğrenci;

1. Matematiksel okuryazarlık becerilerini geliştirebilecek ve etkin bir şekilde kullanabilecektir.

2. Matematiksel kavramları anlayabilecek, bu kavramları günlük hayatta kullanabilecektir.

3. Problem çözme sürecinde kendi düşünce ve akıl yürütmelerini rahatlıkla ifade edebilecek, başkalarının matematiksel akıl yürütmelerindeki eksiklikleri veya boşlukları görebilecektir.

4. Matematiksel düşüncelerini mantıklı bir şekilde açıklamak ve paylaşmak için matematiksel terminolojiyi ve dili doğru kullanabilecektir.

5. Matematiğin anlam ve dilini kullanarak insan ile nesneler arasındaki ilişkileri ve nesnelerin birbirleriyle ilişkilerini anlamlandırabilecektir.

6. Üst bilişsel bilgi ve becerilerini geliştirebilecek, kendi öğrenme süreçlerini bilinçli biçimde yönetebilecektir.

7. Tahmin etme ve zihinden işlem yapma becerilerini etkin bir şekilde kullanabilecektir. Bu kriterlerin konulmasındaki temel amaç; öğrencilerin akıl yürütme, nedensel düşünebilme, yani muhakeme becerilerinin gelişimi, öğrenilen matematik kavramlarının derinlemesine anlamlandırılmasını sağlamaktır. (MEB, 2018) 


\subsection{Araştırmanın Amacı}

Teknoloji, iletişim gibi faktörlerin etkisiyle günümüzde eğitim- öğretim programlarında da sürekli bir değişim ve yenileme adımları atılmaktadır. Eğitimin her düzeyinde olduğu gibi ortaöğretime geçişte de yeni düzenlemeler yapılmaktadır. Dolaysıyla öğrenciler arasında elemelerin yapılabilmesini sağlamak amacıyla her ülkenin farklı uygulamaları bulunmaktadır. ABD, Japonya, İngiltere, Macaristan, Güney Kore ve Hollanda merkezi sınavla liseye öğrenci alırken, Çin, Fransa, İtalya ve Singapur ortaokul bitirme sınavı uygulamaktadır. Bazı ülkelerde ise sadece okul notları, öğretmen görüşü, okul bazlı giriş sınavı da etkili bir yöntem olarak kullanılmaktadır. Türkiye'de ortaöğretime(liselere) öğrencileri yerleştirme sürecinde Milli Eğitim Bakanlığ (MEB)'in uyguladığı merkezi sınavlar belirleyici olmaktadır. Uygulanan merkezi sınavlara göz attığımızda, öğrencilerin liselere yerleştirilmeleri için 2000 yılından itibaren Liselere Giriş Sınavı (LGS) ile yapılmaktaydı. 2004 yılından itibaren Ortaöğretim Kurumları Seçme ve Yerleştirme Sınavı (OKS)'ye geçildi. 2008'den itibaren Seviye Belirleme Sınavları (SBS) uygulanmaya başlandı. 2014'te Temel Eğitimden Ortaöğretime Geçiş (TEOG) kapsamında yapılan merkezi sınavlar uygulanmaya başlandı. En son 2018 yılında TEOG'un kaldırılmasıyla yerine Lise Geçiş Sınavı (LGS) uygulanmaya başlandı. MEB, yeni sınav sistemlerine geçişin sebeplerini öğretim programlarındaki yenilenmeler ve yeni sistemlerin öğrenciler için daha uygun olacağı şeklinde belirtmektedir. Çeşitli dönemlerde uygulanan merkezi sınavlar yöntem ve içerik olarak farklılık göstermektedir. Bu nedenle, yeni uygulanmaya başlanan sınav çeşitleri öğrenci ve öğretmenler için çeşitli güçlüklere neden olduğu, bu güçlüklerin üstesinden gelmek için de soru çeşitlerine uygun kaynakların ve öğretim yaklaşımlarının kullanılmasının önem taşıdığ1 düşünülmektedir. Okullardaki eğitim öğretim sürecinin planlayıcısı ve uygulayıcı öğretmendir. Öğretmenler bu süreci en iyi değerlendirebilecek kişilerdir. Bu yüzden son yillarda uygulanmaya başlanan Matematik LGS sınavlarında öğrencilerin başarılarını artırmak için, bu süreçte öğrenci ve öğretmenlerin hangi güçlükleri yaşadıkları ve LGS sınavının getirdiği güçlüklerin öğretmenlerin matematik eğitimi anlayışlarını nasıl etkilediğinin tespiti önem arz etmektedir. Bu bağlamda çalışmanın amacı; ülkemizde 2018 yılından beri uygulanmaya başlanan Matematik LGS'ye hazırlık sürecinde öğrenci-öğretmen güçlüklerini ve LGS'nin okullarda uygulanan matematik eğitimine yansımalarını öğretmen görüşleri çerçevesinde tespit etmek ve bu doğrultuda önerilerde bulunmaktır.

\subsection{Araştırma Problemi}

Çalışma; “Lise Geçiş Sınavı (LGS)'nın hazırlık sürecindeki güçlükler neleridir? “ ana problemi etrafında şekillenmiştir. Bu kapsamda öğretmenlere çeşitli sorular sorularak çalışmanın alt problemleri oluşturmuştur.

\subsubsection{Araştırmanın alt problemleri}

Çalışmanın Alt problemleri:

1)LGS matematik sorularını çözmede öğrencilerin, LGS matematik sınavlarına öğrencileri hazırlamada öğretmelerin yaşadığı güçlükler ve bu güçlükleri aşmak için sunulan öneriler nelerdir?

2)LGS'de yer alan matematik sorularının özelliklerine yönelik, soruların öğrencilerin düzeyine uygunluk durumunun ve geçmiş dönem liselere geçiş için yapılan sınav soruları arasındaki farklılıklar nelerdir?

3)LGS'nin gerçekleştirilen matematik eğitimini nasıl etkilediğine ilişkin, matematik derslerinde ögretmenlerin yaptıkları sınavlarda kullanılan soru tiplerinin LGS matematik soruları ile uyumluluk düzeyi nedir?

$\mathrm{Bu}$ alt problemlerle birlikte matematik eğitiminde yararlanılan kaynaklara ilişkin, matematik derslerinde kullanılan kaynak kitapların yeterlik durumunun ve MEB'in yayınladığı LGS matematik örnek soruların yararlı olma düzeyinin nasıl değerlendirildiği, belirlenmeye çalışılmıştır.

\section{Yöntem}

$\mathrm{Bu}$ çalışmada; belli bir amaç doğrultusunda katılımcı grubunun bir konu üzerindeki düşüncelerini resmetmeye çalıştığ 1 için tarama modeli benimsenmiştir. Bu yöntemde görüşmeler yolu ile veriler toplanabildiği gibi açık uçlu soruların katılımcılara ulaştırılıp onların yazılı görüşlerini alarak da yapılabilir. Bu şekilde görüş toplama bazı kaynaklarda (Çepni, 2014) anket olarak değerlendirilmektedir. Toplanan veriler içerik analizi ile analiz edilmiştir. Literatürde İçerik analizine ilişkin; "en basit haliyle, fenomenlerin sistematik açıklaması" tanımı geçmektedir (Breakwell, Smith and Wright, 2012). İçerik analizi, katılımcı ve katılımcı olmayan gözlem, mülakatlar, arşivler ve deneysel olmayan, deneysel ve yarı deneysel tasarımlar dahil olmak üzere çok çeşitli bağlamlardan veri, bilgi veya kanıtlara uygulanabilir (Breakwell, Smith ve Wright, 2012).

\subsection{Katılımcilar}

$\mathrm{Bu}$ araştırmada kullanılan örneklem yöntemi “amaçlı örneklem yöntemidir”. Amaçlı örneklem; belirli bir amaçla veya odaklanılan konuyla ilgili olarak örneklemin önceden düşünülüp belirlenmesi demektir (Punch, 2005). Bu açıdan katılımcılar problemin amacı doğrultusunda ortaokul matematik öğretmenleridir. Araştırmanın 
katılımcıları, 2018-2019 eğitim-öğretim yılı ikinci döneminde Türkiye’nin Güneydoğu Anadolu Bölgesinin beş İlindeki ortaokullarda görev yapan ve en az bir dönem 8. Sinıflarda derse girmiş olan 110 matematik öğretmeninden oluşturmaktadır. Çalışmanın katılımcılarına ilişkin bazı özellikler ve frekans değerleri Tablo 1'de gösterilmiştir.

Tablo 1. Katılımcıların Özelikleri

\begin{tabular}{|c|c|c|c|c|c|}
\hline \multicolumn{6}{|c|}{ Özelikler/ Frekans değerleri } \\
\hline \multirow{2}{*}{ Cinsiyeti } & $\mathrm{K} 1 \mathrm{z}$ & Erkek & Belirtilmedi & & \\
\hline & 44 & 65 & 1 & & \\
\hline \multirow{2}{*}{$\begin{array}{l}2019 \text { LGS sorularını } \\
\text { inceleme durumu }\end{array}$} & Evet & Hayır & Belirtilmedi & & \\
\hline & 95 & 10 & 5 & & \\
\hline \multirow{2}{*}{$\begin{array}{l}\text { Mezun olduğu } \\
\text { fakülte }\end{array}$} & Eğitim Fakültesi & Fen Fakültesi & Belirtilmedi & & \\
\hline & 101 & 7 & 2 & & \\
\hline \multirow{2}{*}{ Hizmet yılı } & $1-5 \mathrm{y} 1 \mathrm{l}$ & $5-10$ yil & $10-15$ y1l & 15 ve üzer & \\
\hline & 40 & 36 & 29 & 6 & \\
\hline \multirow{2}{*}{ Okuttuğu sınıflar } & 5.sinif & 6.sinif & 7.sinif & $8 . \sin 1 f$ & \\
\hline & 10 & 16 & 21 & 61 & \\
\hline \multirow{2}{*}{$\begin{array}{l}\text { Okuttuğu sınıf } \\
\text { mevcutları }\end{array}$} & 20-25 öğrenci & 25-30 öğrenci & 30-35 öğrenci & 35-40 öğrenci & 40 ve üzeri \\
\hline & 18 & 44 & 25 & 19 & 7 \\
\hline
\end{tabular}

\subsection{Veri Toplama Aracı / Araçları}

$\mathrm{Bu}$ çalışmada veri toplama aracı olarak araştırmacılar tarafından hazırlanan yarı yapılandırılmış bir görüş formu kullanılmıştır. Hazırlanan formun geçerlilik ve güvenirliğini sağlamak amacıyla üç farklı araştırmacı tarafından ayrı ayrı pilot uygulamalar( her bir araştırmacı formu 10 farklı öğretmene uygulamıştır) yapılmıştır. Elde edilen veriler analiz edilip karşılaştırılıp görüşme formunun son hali oluşturulmuştur. $\mathrm{Bu}$ formda öğretmenlere açık uçlu sorular yöneltilmiş ve LGS matematik sınavlarında yaşanan sorunlardan bazıları betimlenmeye çalışılmıştır. Bu soruların genel kapsamı Öğretmenlerin öğrencileri LGS sınavına hazırlamada yaşadıkları güçlüklerin ve bu güçlükleri aşmak için önerilerinin neler olduğudur. Bu amaçla 15 açık uçlu soru hazırlanmıştır. Ancak iki akademisyen ve 3 öğretmenle yapılan ön görüşmelerde hazırlanan sorulardan bazılarının benzer veya çok yakın cevaplar üreteceği kanaatine varılmıştır. Bu açıdan tekrar niteliğindeki sorulardan sekizi elenmiştir. Daha sonra kalan sorularla yeniden bir ortaokul özelindeki matematik öğretmenlerine gidilmiş ve hazırlanan formun değerlendirilmesi istenmiştir. Elde edilen sonuçlar bu araştırmanın yürütülmesi için yeterli bir zemine sahip olduğu kanaatine varılmış ve formun bu son hali araştırma için kullanılmıştır. Bu araştırma kapsamında araştırma katılan öğretmenlerin gönüllülük esasında katılımları tercih edilmiş ve bu açıdan samimi cevaplar verdiği kabul edilmiştir. Bununla birlikte bazı öğretmenlerin yeterli cevaplar vermediği hatta bazı sorulara hiç cevap vermedikleri görülmüştür. Bu formlar soru bazında değerlendirme dışı bırakılmış ancak bütün olarak değerlendirme dışı bırakılan görüşme formu olmamıştır.

\subsection{Verilerin Analizi}

Matematik LGS sınavlarında öğrencilerin başarılarını artırmak için, bu süreçte öğrenci ve öğretmenlerin hangi güçlükleri yaşadıkları ve LGS sınavının getirdiği güçlüklerin öğretmenlerin matematik eğitimi anlayışlarını nasıl etkilediğinin tespiti amacıyla yapılan bu çalışmada bütün görüşmeler kayıt altına alınmış ve transkript edilmiştir. Veriler transkript edildikten sonra nitel veri analiz tekniği olan içerik analizine tabi tutulmuştur. Elde edilen verilere yönelik analizler farklı araştırmacılar (2 araştırmacı verileri analiz etmiş 3. araştırmacı analizlerin karşılaştırmasını yapmıştır) tarafından birlikte yapılmış ve kodlamalarla ilgili anlaşmazlıklar ortak bir karara varılana dek tartışılmıştır. Bu kodlamalara ilişkin temalar ve bu temalara ait alt temalar belirlenmiştir. Araştırmanın amacı doğrultusunda bulgular kısmında örnekleri ile ayrıntılı olarak analiz edilip sunulmuştur.

\section{Bulgular}

Öğretmen ve öğrenciler için ders kitabı hem ders kazanımlarının elde edilmesi hem de öğrencilerin sınavlara hazırlanmasında kullanılabilen en önemli kaynak özelliğini taşımaktadır. LGS sorularının matematik ders kitabında yer alan sorularla uyumlu olması öğrenci ve öğretmenlerin ders kitabını daha yoğun ve istekli kullanmalarına katkı sağlayacaktır. Ders kitaplarında bulunan sorularının LGS sorularıyla uyumlu olması aynı zamanda yardımcı ders kitaplarına duyulan ihtiyacı azaltacaktır. Bu konuya ilişkin öğretmen görüşlerinin neler olduğunu belirlemek amacıyla öğretmenlere aşağıdaki soru yöneltilmiştir.

"LGS matematik sınavına yönelik öğrencilerinizi yetiştirmek için ders kitaplarından yararlandığınızı düşünüyor musunuz? Neden?” Bu sorudan elde edilen veriler Tablo 2'de gösterilmektedir. 
Tablo 2. LGS Matematik Sınavına Yönelik Öğrencilerin Yetiştirilmesinde Öğretmenin Ders Kitaplarından Yararlanma Durumu

\begin{tabular}{|c|c|c|c|}
\hline Öğretmenin & \multicolumn{2}{|c|}{ Ders Kitaplarından Yararlanma Durumu } & \multirow{2}{*}{$\begin{array}{c}\text { Frekans } \\
4\end{array}$} \\
\hline \multirow{8}{*}{ Evet } & \multirow{5}{*}{ Çünkü } & $\begin{array}{l}\text { Soru çeşitliliği sağlamak ve müfredat } \\
\text { zorunluluğu }\end{array}$ & \\
\hline & & LGS'de çıkacak benzer soru beklentisi & 16 \\
\hline & & Yeterlidir & 2 \\
\hline & & Kazanımlara yöneliktir & 6 \\
\hline & & Eğitim eşitliği sağlamakta & 2 \\
\hline & \multirow{3}{*}{ Ancak } & Farklı kaynaklardan da yararlanıyorum & 5 \\
\hline & & Yeterli değil & 3 \\
\hline & & LGS için yetersiz & 3 \\
\hline \multirow{3}{*}{ Hayır } & \multirow{3}{*}{ Çünkü } & LGS için yeterli değil & 13 \\
\hline & & Yeterli değil & 5 \\
\hline & & Bilgi düzeyinde & 2 \\
\hline \multirow{4}{*}{ Kismen } & \multicolumn{2}{|c|}{ Kazanımlara yönelik } & 4 \\
\hline & \multicolumn{2}{|c|}{ Soru sayıs1 yetersiz } & 2 \\
\hline & \multicolumn{2}{|c|}{ Sinava yönelikse } & 2 \\
\hline & \multicolumn{2}{|c|}{ Soru çeşitliliği ve müfredat zorunluluğu (4) } & 4 \\
\hline
\end{tabular}

Tablo 2'deki verilerin analizi ele alındığında matematik öğretmenlerinin önemli bir kısmı (\%54) "Evet" cevabını verdikleri görülmektedir. Matematik öğretmenlerinin evet cevabına nedensel olarak ilişkilendirdiğ gerekçelerde çoğunlukla "LGS'de benzer soru beklentisi" olduğu görülmektedir. Bunun yanında "kazanımlara yönelik oluşu” önemli bir gerekçe olarak görülmektedir. Diğer bir önemli kategori de "soru çeşitliliği sağlamak ve müfredat zorunluluğu" olduğu görülmektedir. Bu kategori hem LGS'de çıkacak benzer sorularla ilişkili hem de kazanımlarla ilişkili olduğu görülmektedir. Bu durumda öğretmenlerin çoğunlukla ders kitaplarından yararlanırken LGS'ye yönelik benzer soru beklentisi ve müfredata uyma zorunluluğunun öne çıktığı söylenebilir. "Kısmen" cevabı veren öğretmenler için öncelikle kazanımlara yönelik ve sınava yönelik kategorileri "Evet" cevabı veren öğretmenlerin cevaplarına paralel görülmektedir. Bir diğer kategoride "soru çeşitliliği ve müfredat zorunluluğu" kategorisidir. Bu da "Evet" cevabı veren öğretmenlerle aynı kategoride görülmektedir. "Hayır" cevabı veren öğretmenlerin gerekçeleri sınıflandırıldığında çoğunlukla "LGS için yeterli değil” cevabı baz alınabilir. Ancak burada frekans olarak düşük de olsa ders kitaplarının "bilgi düzeyinde" yani kavramsal düzeyde olduğunun belirtilmesinin önem taşıdığı düşünülmektedir.

Matematik öğretmenlerinin öğrencilerini LGS sınavlarına hazırlamak için yardımcı ders kitaplarından yararlanma düzeyleri ve nedenlerinin ne olduğunu belirlemek amacıyla aşağıda belirtilen soru yöneltilmiştir. "LGS matematik sınavına yönelik öğrencilerinizi yetiştirmek için yardımcı ders kitaplarından yararlandı̆̆ınızı düşünüyor musunuz? Neden? Bu sorudan elde edilen veriler Tablo 3'de gösterilmektedir.

Tablo 3. LGS Matematik Sınavına Yönelik Yardımcı Ders Kitaplarından Yararlanma Durumu

\begin{tabular}{|c|c|c|c|}
\hline $\begin{array}{l}\text { Öğretmenin } \\
\text { Cevabı }\end{array}$ & \multicolumn{2}{|c|}{ Ders Kitaplarından Yararlanma Durumu } & \multirow{2}{*}{$\begin{array}{c}\text { Frekans } \\
26\end{array}$} \\
\hline \multirow{7}{*}{ Evet } & \multirow{7}{*}{ Çünkü } & Farklı soru tarzları için & \\
\hline & & Daha yararlı & 4 \\
\hline & & Ders kitapları yetersiz & 18 \\
\hline & & LGS sorularına benzer & 2 \\
\hline & & Öğrencilerin eksikliklerini tamamlamak için & 5 \\
\hline & & Pekiştirme amaçlı & 2 \\
\hline & & Sınava yönelik olduğu için & 14 \\
\hline Hayır & Çünkü & Ders kitapları ve EBA'yı kullanıyorum & 3 \\
\hline Kismen & & Farklı soru tarzları için & 1 \\
\hline
\end{tabular}

Tablo 3'teki verilerin analizi dikkate alındığından baskın görüş öğretmenlerin LGS sınavına yönelik olarak yardımcı ders kitaplarını kullandıklarını görmekteyiz. Bunun en önemli nedenleri arasında yardımıcı ders kitaplarının farklı soru tarzlarına sahip olması gelmektedir. Diğer bir başat kategori ise ders kitaplarının LGS açısından yetersiz oluşudur. Bir diğer kategori olan "Öğrencilerin eksikliklerini tamamlamak için” şeklinde verilen cevaplar yukarıda verilen diğer iki kategoriyi tamamlar niteliktedir. Bununla birlikte doğrudan "sınava yönelik olduğu için" kategorisi müfredata yönelik ders kitaplarının dışında, doğrudan bir amaç ifade ettiği görülmektedir. Öğretmenlerin verdikleri "hayır” cevaplarında kategorik olarak sadece "Ders kitapları ve EBA'yı kullanıyorum” kategorisi göze çarpmaktadır. 
LGS matematik sorularını çözmede öğrencilerin başarısızlık nedenlerini belirlemek amacıyla öğretmenlere aşağıdaki soru yöneltilmiştir."LGS matematik sorularını çözmede öğrencilerinizin ne tür zorluklar yaşamış olabileceğini düşünüyorsunuz?" Matematik öğretmenlerinin soruya vermiş oldukları cevapların analizi Tablo 4'da görülmektedir.

Tablo 4. LGS Matematik Sorularını Çözmede Öğrencilerinizin Yaşadığı Zorluklar

Öğretmenin Cevabı

Anlama ve yorumlama eksikliği

Alınan eğitimin yetersizliği

Anlama ve yorumlama eksikliği + işlem becerisi

Öğrencilerin düzeyinin üstünde

Ön yarg1 + anlama ve yorumlama eksikliği

Psikolojik etkenler

Süre + anlama ve yorumlama eksikliği

Süre sorunu

Uzun sorular

Uzun sorular + ön yarg1

Diğer

Tablo 4'teki verilerin analizi ele alındığında “Anlama ve yorumlama eksikliği” kategorisi baskın bir şekilde görülmektedir. Genel olarak tespit edilme frekansı 76'dır. Buna ek olarak "süre" önemli bir sorun olarak görülmektedir. Süre kategorisinin Genel olarak görülme sıklığı 16'dır. Diğer kategoriler ele alındığında uzun sorular önemli bir problem olarak görülmektedir. Benzer şekilde önyargı (sorular zor önyargısı) 11'dir Tüm bu kategoriler ele alındığında genel olarak anlama ve yorumlama becerisine eşlik eden bazı olguların olduğu söylenebilir.

Matematik öğretmenlerinin önceki yıllarda yapılan merkezi sınavlar ile LGS sınavları arasındaki farklılığ öğretmenlerin nasıl değerlendirdiklerini ve bu farklılığın matematik eğitimini nasıl etkilediğini belirlemek amaciyla sorulan soru "Geçmiş dönemde liselere geçiş için yapllan sınav sorulart ile 2017-2018 ve 20182019'da çıkan sorular arasında ne tür farklılıklar görmektesiniz? Bu farklılıkların yapmakta olduğunuz eğitimi nasıl etkilediğini veya etkileyeceğinizi düşünüyorsunuz? "şeklinde olmuştur. Matematik öğretmenlerin bu soruya verdikleri cevapların analizi Tablo 5'de görüldüğü gibidir

Tablo 5. Daha Önceki Merkezi Sınavlar İle LGS Sınavları Arasındaki Farklılıklar Ve Bu Farklılığın Matematik Eğitimini Etkileme Durumuna İlişkin Bulgular

\begin{tabular}{|c|c|c|c|}
\hline LGS Öncesi Merkezi Sınavlar & Frenkans & LGS & Frenkans \\
\hline \multirow[t]{4}{*}{ Sadece bilgi ve işleme dayalı } & \multirow[t]{4}{*}{32} & Anlama ve yorumlama & 24 \\
\hline & & Analiz-sentez düzeyinde & 8 \\
\hline & & Bilgiyi kullanma becerisi & 2 \\
\hline & & $\begin{array}{l}\text { Soru niteliklerinde dengeye ulaşılmaktadır } \\
\text { (Öğrenci düzeyine daha uygun) }\end{array}$ & 21 \\
\hline \multirow[t]{2}{*}{$\begin{array}{l}\text { Bütün öğrencileri motive } \\
\text { etmekteydi }\end{array}$} & 2 & Sadece başarılı öğrencileri motive etmekte & 2 \\
\hline & & Üst düzey beceriler & 5 \\
\hline TEOG soruları daha iyi idi & 3 & Daha zor sorular & 11 \\
\hline $\begin{array}{l}\text { Öğrenci seviyesine ve müfredata } \\
\text { uygundu }\end{array}$ & 4 & & \\
\hline Önceki sorular kolay & 5 & Ayırt edici & 2 \\
\hline
\end{tabular}

Tablo 5'teki bulgular dikkate alındığında önceki dönem sınavlarına ilişkin öğretmen görüşlerini olumlu ve olumsuz görüşler olarak değerlendirmek mümkündür. Önceki merkezi sınav değerlendirmelerinde sadece bilgi ve işleme dayalıydı ifadesinin karşısında, çoğunlukla "LGS anlama ve yorumlama", "analiz-sentez" "bilgiyi kullanma becerisi gerektirmektedir" ifadelerine yer verildiği görülmektedir. Bu farklılığa ilişkin değerlendirmenin çoğunlukla olumlu olduğunu ve öğretmenlerin değişimini/kendilerini yenilemeleri gerektirdiğini gösteren ifadelere yer verildiği görülmektedir. Ancak bunun yanında olumsuz görüşlere de rastlanmaktadır. Bunlar arasında "eğitimi ve motivasyonu olumsuz etkiledi”, özgüveni olumsuz etkilemekte", “tüm öğrencilere hitap etmiyor” görüşlerini de görmek mümkündür.

Bu araştırma kapsamında LGS matematik sınavlarına öğrencileri hazırlamada matematik öğretmenlerinin yaşadığı zorlukları belirlemek amacıyla sorulan bir diğer soru; "LGS matematik sınavlarına öğrencilerinizi 
yetiştirirken ne tür zorluklar yaşadığınızı düşünüyorsunuz" şeklinde bir soru sorulmuştur. Matematik öğretmenlerinin bu soruya vermiş oldukları cevapların analizi Tablo 6'da görülmektedir.

Tablo 6. "LGS Matematik Sınavlarına Öğrencileri Yetiştirmede Yaşanan Zorluklara İlişkin Bulgular

\begin{tabular}{|c|c|c|c|}
\hline Karșılașılan problem & Frekans & İlişkili sonuç & Frekans \\
\hline $\begin{array}{l}\text { Öğrencilerde görülen düşünme } \\
\text { eksikliği }\end{array}$ & 5 & Anlamakta zorluk & 2 \\
\hline \multirow[t]{2}{*}{$\begin{array}{l}\text { Ezberci eğitimin neden olduğu } \\
\text { sorunlar }\end{array}$} & \multirow[t]{2}{*}{7} & $\begin{array}{l}\text { Öğrencilerde görülen düşünme eksikliği } \\
\text { problemi }\end{array}$ & 3 \\
\hline & & Öğretmenler sürece hazır değil & 2 \\
\hline \multirow{2}{*}{$\begin{array}{l}\text { Kitap okuma alışkanlığının } \\
\text { yetersizliği }\end{array}$} & \multirow[t]{2}{*}{6} & Anlamakta zorluk & 2 \\
\hline & & Yorum yapma becerileri düşük kalmakta & 3 \\
\hline \multirow{2}{*}{$\begin{array}{l}\text { LGS'nin üst düzey sorular } \\
\text { içermesi }\end{array}$} & \multirow[t]{2}{*}{13} & Anlamakta zorluk & 4 \\
\hline & & $\begin{array}{l}\text { Bu problemlerle uğraşmak zaman ve } \\
\text { verim açısından problem olmaktadır }\end{array}$ & 4 \\
\hline $\begin{array}{l}\text { Müfredat ve sınav sorularının } \\
\text { uyuşmazlığ } 1\end{array}$ & 11 & Öğrenciler sınava ilgi göstermiyor & 5 \\
\hline $\begin{array}{l}\text { Yeterli sayıda } \\
\text { ulaşamama sorunu }\end{array}$ & 3 & & \\
\hline \multirow{3}{*}{$\begin{array}{l}\text { Öğrencilerin bilgi } \\
\text { yapılarının sorunlu olması }\end{array}$} & \multirow[t]{3}{*}{23} & Motivasyon problemi & 4 \\
\hline & & Genele ulaşmada yaşanan problem & 4 \\
\hline & & $\begin{array}{l}\mathrm{Bu} \text { problemlerle uğraşmak zaman ve } \\
\text { verim açısından sorun olmaktadır }\end{array}$ & 2 \\
\hline Matematiğe karşı önyarg1 & 1 & Motivasyon & 2 \\
\hline $\begin{array}{l}\text { Sinav beklentisi ve müfredat } \\
\text { uyuşmazlığ } 1\end{array}$ & 2 & Motivasyon & 2 \\
\hline $\begin{array}{l}\text { Öğrencilerde görülen özgüven } \\
\text { eksikliği }\end{array}$ & 2 & Anlamakta zorluk & 2 \\
\hline $\begin{array}{l}\text { Problem çözme stratejilerinde } \\
\text { eksiklik }\end{array}$ & 6 & Anlamakta zorluk & 3 \\
\hline $\begin{array}{l}\text { Yeterli kaynak bulamama } \\
\text { sorunu }\end{array}$ & 4 & & \\
\hline
\end{tabular}

Tablo 6 dikkate alınarak Matematik öğretmenlerinin "LGS matematik sınavlarına öğrencilerinizi yetiştirirken ne tür zorluklar yaşadığınızı düşünüyorsunuz" sorusuna verdikleri cevaplar incelendiğinde en çok karşılaşılan problemin "öğrencilerin bilgi alt yapıları sorunlu” kategorisi olmuştur. Bu kategori ile ilişkili olarak ileri sürülen ilişkili sonuçlar "öğrencilerde görülen motivasyon problemi”, "sınıf içi öğrenci kitlesinin tamamına ulaşamama problemi”, "matematik derslerinde yeterli bir verim elde etmek için zamanın sınırlı olması" gibi problemler görülmektedir. Buna benzer olarak "LGS üst düzey sorular içermektedir" şeklindeki düşünceye öğretmenlerin ifadelerinde ağrılıklı olarak görülmektedir. İlişkili sonuçlarda öğrencilerin "anlamakta zorluk yaşadıkları" ve “ zaman ve verim açısından problem” oluşturduğu görülmektedir. Karşılaşılan problemlerle ilişkili ortaya çıkan sonuçlara dikkat edildiğinde özellikle öğrencilerin "anlamakta zorluk" ve buna yakın olarak "motivasyon problemi” yaşadıkları görülmektedir.

Matematik öğretmenlerine sorulan bir diğer soru "LGS matematik sınavlarında çıkabilecek sorulara ilişkin MEB'in yayınladığı örnek soruların sınav hakkında bilgi sahibi olmak için yeterli olduğunu düşünüyor musunuz? "şeklinde bir soru olmuştur. Bu soru ile aşağıdaki hususların belirlenmesi amaçlanmıştır;

Soru tipleri hakkında elde edilen bilgiler aynı zamanda kitap yazarları tarafindan hazırlanacak ders kitapları ve yardımcı ders kitapları için yararlı olacaktır. Bu amaçla uygulanmaya başlanan LGS matematik sınavlarında çıkabilecek soru tiplerine ilişkin MEB örnek sorular yayınlamaktadır. Öğgretmenlere sorulan soru ile MEB'in yayınladığı örnek soruların öğrenci ve öğretmenlere çıkacak sınav soruları hakkında yeterli bilgi verip vermediği belirlenmeye çalışılmaktadır. Matematik öğretmenlerinin bu soruya vermiş oldukları cevapların analizi Tablo7'de görülmektedir. 
Tablo 7: LGS Matematik Örnek Soruların Sınav Hakkında Yeterli Bilgi Verme Durumuna İlişkin Bulgular

\begin{tabular}{|c|c|c|c|c|c|}
\hline $\begin{array}{l}\text { Yeterlik } \\
\text { durumu }\end{array}$ & Frekans & Nitelik & Frekans & Nedene ait görüsşler & Frekans \\
\hline \multirow[t]{4}{*}{ Yeterlidir } & \multirow[t]{4}{*}{65} & \multirow{3}{*}{$\begin{array}{l}\text { Sinava yönelik } \\
\text { ipucu niteliğinde }\end{array}$} & \multirow[t]{3}{*}{13} & Soru sayısı artırılmalıdır & 6 \\
\hline & & & & Yararlı & 2 \\
\hline & & & & LGS ile paralel & 5 \\
\hline & & Sorular yeterlidir & 52 & LGS ile paralel & 23 \\
\hline \multirow[t]{3}{*}{ Yeterli değil } & \multirow[t]{3}{*}{18} & & & Soru sayısı artırılmalıdır & 5 \\
\hline & & & & Ancak yararlı & 10 \\
\hline & & & & Daha basit & 9 \\
\hline \multirow[t]{4}{*}{ Kismen } & \multirow[t]{4}{*}{11} & & & Soru sayısı artırılmalıdır & 1 \\
\hline & & & & Ancak yararlı & 2 \\
\hline & & & & Daha basit & 3 \\
\hline & & & & LGS ile paralel & 4 \\
\hline
\end{tabular}

Tablo 7'deki bulgular incelendiğinde öğretmenlerin özellikle sınava yönelik örnek soruların sınav hakkında bilgi sahibi olmak için "yeterli” olduğunu belirtmişlerdir. Nitelik olarak sınava yönelik ipucu niteliğinde olduğu belirtilen soru sayısının artırılması gerektiği ve bu tür uygulamaların yararlı olduğunu öğretmenler ifade etmiştir. "Yeterli değil" şeklindeki kategoride nedene ait görüşler incelendiğinde "MEB sorularının LGS'ye göre daha basit olduğu", "soru sayısının artırılması gerektiği” gibi görüşler ileri sürülmüştür." Kısmen kategorisinde görülen cevapların daha çok “yeterli değil” kategorisine yakınsadığı görülmektedir.

Öğrencileri LGS tipindeki sınavlara ve üst öğrenimlere hazırlamada matematik öğretmenlerinin nelerin yapılması gerektiğine ilişkin düşünceleri büyük önem taşımaktadır. Bu amaçla, aşağıdaki soru yöneltilmiştir.

"Mevcut durumda öğrencilerin daha yüksek düzeyde başarı göstermeleri için önerileriniz nelerdir?”. Bu soruya ilişkin matematik öğretmenlerinin vermiş olduğu cevaplar şekil 1'de görüldüğü gibidir. Şekil 1'deki verilerin oluşturulmasında frekans sıklıklarına bağlı olarak merkeze yakın yerleştirme, renk tonu koyuluğu ve ilişkilendirilen kavramlar için tek ve çift yönlü oklar kullanılmıştır.

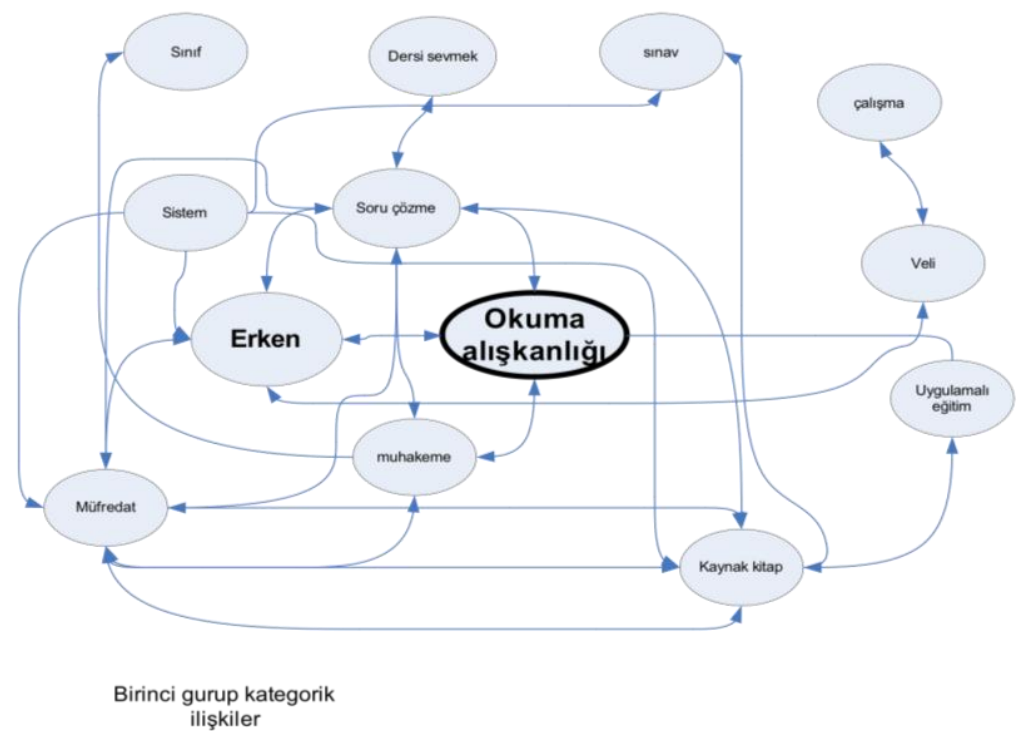

Şekil 1. İlişki Şemasındaki Ana Kategoriler Ve Aralarındaki İlişkiler

Şekil 1'de ana kategoriler ve aralarındaki ilişkiler görülmektedir. Yapılan analize göre en fazla frekans “okuma alışkanlığı”" frekansında görülmüştür(23). İkinci olarak en sık tekrarlanan frekans (21) “erken” ifadesi ile ilgilidir. "Erken" ifadesi önceki sınıflardan itibaren başlaması gereken bir hazırlığın olması gerektiğ değerlendirmesidir. Ancak burada dikkat edilmesi gereken bir diğer kategori olan "muhakeme" kategorisidir. Frekansı diğerlerine göre daha düşük (10) olmasına rağmen ilişkilendirildiği diğer kategori sayısı daha fazladır. Bunun dışında bir diğer kategori olan soru çözme (11) kategorisi de önemli bağlara sahip olduğu görülmektedir. Bu kategorilerin doğrudan ilişkili olduğu ikinci düzey kategori “motivasyon” olmuştur. Şekil 2'de buna ilişkin ilişki ağı görülmektedir. Buna göre okuma alışkanlığı önyargıyı ortadan kaldırmak için kullanılmalıdır. Dersi sevdirmenin de önyargıyı kaldırabileceğine ilişkin görüşler ortaya çıkmıştır. 


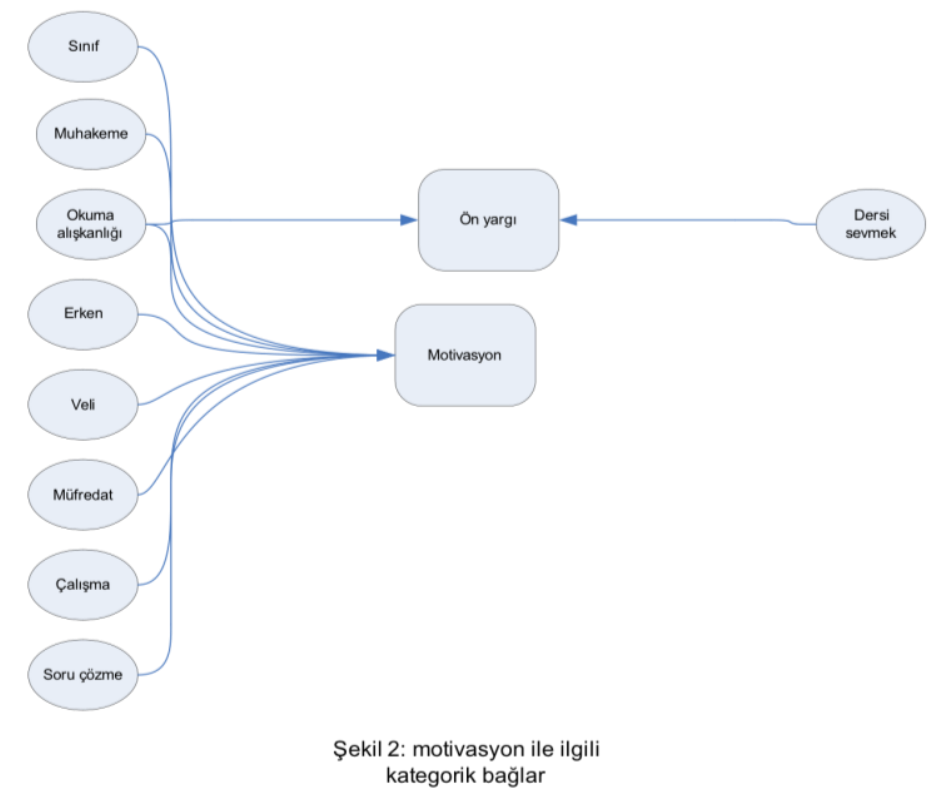

Şekil 2. İlişki Şemasındaki Ana Kategoriler ve Aralarındaki İlişkiler

\section{Tartışma ve Sonuç}

Çalışmanın amacı, LGS'ye hazırlık sürecinde öğrenci-öğretmen güçlüklerini ve LGS'nin okullarda uygulanan matematik eğitimine yansımalarını öğretmen görüşleri çerçevesinde tespit etmek ve bu doğrultuda önerilerde bulunmaktır. Bu amaç doğrultusunda veriler içerik analizi tekniğiyle derinlemesine ve ayrıntılı olarak bulgularda incelendi. Elde edilen bulgular bir bütün olarak değerlendirildiğinde bu araştırma kapsamında görülen en yaygın sorun anlama ve yorumlama sorunu olduğu görülmektedir. Bunun çok çeşitli nedenleri olabilmektedir. Ancak genel olarak matematik öğretmenlerinin doğrudan sınava yönelik hedeflerini belirledikleri söylenebilir. $\mathrm{Bu}$ durum bir takım önemli sorunları beraberinde getirmektedir. Örneğin öğrencilerdeki zihinsel gelişimlerin aşamalarını kaçırmalarına veya öğrenme stillerine dikkat etmemelerine yol açabilmektedir. Literatürde yapılan çalışmalar da benzer sonuçlar ortaya çıkmıştır. (Francisco ve Maher, 2005; Generazzo, 2011)

Bulgularda ortaya çıkan önemli sonuçlardan bir tanesi de; matematik öğretmenlerinin MEB ders kitaplarının LGS sınavına yönelik ihtiyaçları karşılamada yetersiz olduğunu düşündükleri görülmektedir. Sonuç olarak, MEB ders kitaplarının bilgiyi yapılandırmaya yönelik olduğunu ancak LGS sınavının daha çok üst düzey bir takım beceriler olan eleştirel düşünme, anlama ve yorumlama, problem çözme gibi beceriler gerektirdiği ifade edilebilir. Verilerin analizi bir bütün olarak dikkate alındığında görülebileceği gibi MEB ders kitaplarının LGS yönelik içeriğe sahip olma amacı sınırlıdır. Çünkü ders kitapları öncelikle genel öğrenci kitlesine hitap etmek zorundadır. Ancak bu kapsamda LGS sınavının ölçme ve değerlendirme açısından ayırt edici olması gerektiği anlaşılırdır. Ancak bu durumda LGS sınavına hazırlanan öğrencilerin LGS sınavına hazırlanmasında yardımcı ders kitaplarından yararlanmaları kaçınılmaz olduğu düşüncesi doğmaktadır. Bu durum yukarıda ele alınan bulgularda da net olarak görülebileceği gibi LGS sorularının bilgiyi işleme/ilişkilendirme, muhakeme, eleştirel düşünme üst düzey beceriler gerektirdiği (tablo 5, tablo 7) ve bu becerilerin de salt kavramsal bilgiden daha fazla olduğu ifade edilmektedir. (Pulley, 2010)

Araştırmanın amacı doğrultusunda katılımcılara yöneltilen "LGS matematik sınavına yönelik öğrencilerinizi yetiştirmek için yardımcı ders kitaplarından yararlandığınızı düşünüyor musunuz? Neden?" sorusuna ilişkin bulgular ele alındığında çoğunlukla "Evet" cevabı verdikleri görülmektedir. Genel bir bakış açısı ile değerlendirildiğinde ders kitaplarından yararlanma durumlarına verdikleri cevaplarla tutarlı görünmektedir. Buna göre katılımcıların yardımcı ders kitaplarına yönelik olumlu bir yaklaşım içinde olduğunu söylemek mümkündür. Bu yönüyle öğrencileri LGS sınavına hazırlama çabası içinde olan öğretmenlerin yardımcı ders kitapların genel olarak hem soru bazında hem de yardımcı bir kaynak olarak öğrencilerin eksikliklerini tamamlamak için kullandıkları görülmektedir. Esas olarak ele alındığında çeşitli kaynaklardan bilgi edinilmesi kuşkusuz hatalı bir davranış olamaz. Ancak öğrenciler için bunun zorunlu tutulmaması eğitimde eşitlik açısından önem taşımaktadır. Hiebert ve Grouws, (2007) yaptıkları çalışmada benzer bir sonucu vurgulamaktadırlar.

Ortaokul matematik öğretmenlerinin "LGS matematik sorularını çözmede öğrencilerinizin ne tür zorluklar yaşamış olabileceğini düşünüyorsunuz?" şeklinde soruya verdikleri cevaplar analiz edildiğinde genel çoğunluk "Anlama ve yorumlama" sorunu olarak göze çarpmaktadır. Bununla birlikte ifade edilen "süre sorunu" da esasında anlama ve yorumlama hızı ile ilişkili olduğu görülmektedir. Aynı şekilde burada görülen "uzun sorular" 
kavramı da öğrencilerin hızlı bir şekilde çözüme gidecekleri değil daha çok problemi bütünü ile hatırlama ve kavramaya bağlı olarak ortaya çıkan sorunlar olduğu görülmektedir. Bu araştırmanın farklı yerlerinde ortaya çıkan öğrencilerin "okuma alışkanlığının” geliştirilmesi bu becerilerinin geliştirilmesine yönelik bir tedbir olarak değerlendirilmektedir. Bir diğer olgu öğrencilerde görülen matematiğe ve matematik problemlerine karş1 görülen ön yargıdır. Bu daha başlangıçta öğrenciyi anlamaya çalışmaktan uzaklaştıran bir olgu olduğundan, özellikle dikkate alınması gereken bir durumdur. Araştırmacılar açısından anlama sorunu daha çok ilişkilendirme ve muhakeme ile ilgili olduğu yönündedir. İkinci bir açıklama olarak bilgi sınıflandırılmasından kaynaklanan bir sorun olabilir. Bu da şeylerin ne olduğu bilgisi yani tanıma bilgisi ve şeylerin nasıl yapıldığı bilgisidir (Pears, 2004). Buna göre öğrencinin odaklandığ 1 bilgi türünün önemli olduğu düşünülmektedir. Daha çok nasıl yapıldığının ezberlendiği tür bir bilgilenme sürecinden geçmiş öğrencilerin bu tür bir işlemi gerektiren sorulara cevap verebildikleri ancak ilişkilendirme ve muhakeme gerektiren problemlerde başarısız olduğunu düşündürmektedir. Bu neden öğrencilerin özellikle muhakeme becerilerinin geliştirilmesine yönelik bir eğitim düzenlemesi yapılması gerektiği kanısı doğurmaktadır.

Ortaokul matematik öğretmenlerinin "Geçmiş dönemde liselere geçiş için yapılan sınav soruları ile 20172018 ve 2018-2019'da çıkan sorular arasında ne tür farklılıklar görmektesiniz? Bu farklılıkların yapmakta olduğunuz eğitimi nasıl etkilediğini veya etkileyeceğinizi düşünüyorsunuz?" sorusuna verdikleri cevapların analizi dikkate alındığında önceki yıllara ilişkin olarak "Sadece bilgi ve işleme dayalı" ifadesinin göze çarptığ görülmektedir. Bu durum yukarıda ifade edilen ilişkilendirme ve muhakeme açıklaması ile tutarlı görünmektedir. LGS sınav sorularının çoğunlukla "Anlama ve yorumlama" ve "Analiz-Sentez düzeyinde" olması bu duruma yönelik geçerli bir açıklama olduğunu düşündürmektedir. Ortaokul matematik öğretmenlerinin değerlendirmesine göre bu durum üst düzey becerilerin ayırt ediciliği açısından önemli gördüklerini söylemek mümkündür. Ayrıca bulgulardan elde edilen "ayırt edici" yani seçici cevabının varlığı öğretmenlerin de bu konuda benzer düşünceler taşıdığını göstermektedir.

Katılımcılara yöneltilen "LGS matematik sınavlarına öğrencilerinizi yetiştirirken ne tür zorluklar yaşadığınızı düşünüyorsunuz" sorusu için bulgular dikkate alındığında "öğrencilerin bilgi alt yapıları sorunlu” kategorisinin başat olduğu ve bunun çeşitli sorunlara yol açtığı görülmektedir. Bilgi alt yapısı sorunlu olan bireyler yeterli düzeyde ilişkilendirme yapamayacakları için istenen düzeyde düşünme ve anlamayı da gerçekleştirmede zorlanacaklardır. Benzer şekilde "motivasyon problemi", öğrencilerin aldıkları eğitimi sürdürmelerinde önemli bir etkendir Bu soruya ait bulgularda dikkat çeken bir diğer kategorinin "LGS üst düzey sorular içermektedir" olduğudur. $\mathrm{Bu}$ da yine doğrudan veya dolaylı olarak öğrencilerin bilgi alt yapısı ile ilişkilendirilebilecek bir durumdur. Öğrenci bilgi seviyesinin yetersiz olmasından mı yoksa LGS nin üst düzey sorular içermesi mi? Önemli bir sorunsal görünmektedir. Öğretmenlerin ifadeleri analiz edildiğinde "ilişkili sonuç" sınıflandırmasında açıkladıkları öğrencilerin "anlamakta yaşadıkları zorluk" göze çarpmaktadır. Buna yönelik yine bu araştırmada elde edilen sonuçlardan biri olan öğrencilerin genel olarak okuma alışkanlıklarının olmadığı ve bununda öğrencilerde anlama problemi yarattığı şeklindeki açıklamadır.

$\mathrm{Bu}$ araştırma açısından bu soruda elde edilen bulgular arasında "Ezberci eğitimin neden olduğu sorunlar" kategorisinin önemli olduğu düşünülmektedir. Buna göre "öğrencilerde görülen düşünme eksikliğgi” problemi önemli bir sorundur. Bu esasında bu araştırmanın farklı yerlerinde görülen muhakeme etme sorununun başka bir isimle adlandırılmasıdır. Tüm bunlar birleştirildiğinde anlama zorluğu yaşayan öğrencilerin düşünme veya muhakeme sorunu yaşadığı ve bunun çok önemli sorunlara yol açtığ 1 söylenebilir.

Katılımcılara sorulan "LGS matematik sınavlarında çıkabilecek sorulara ilişkin MEB'in yayınladığı örnek soruların sınav hakkında bilgi sahibi olmak için yeterli olduğunu düşünüyor musunuz?" Şeklinde soruya ait bulgular dikkate alındığında çoğunlukla MEB'in yayınlamış olduğu soruların yeterli olduğunu ancak soru sayısının artırılması gerektiği şeklindedir. Buna ek olarak yukarıda da belirtildiği gibi bu tip soruların kaynak kitap içine yerleştirilerek farklı düzeylere hitap edebilen bir tasarımına yol açması gerektiği kanısıdır.

Matematik öğretmenlerine yöneltilen “öğrencilerin daha yüksek düzeyde başarı göstermeleri için önerileriniz nedir?" sorusuna verdikleri cevapların birinci döngü şematik analizi dikkate alındığında (şekil 1) öğretmenlerin önemli bir oranı öğrencilerdeki okuma alışkanlığının yetersizliğine vurgu yaptıkları görülmüştür. Okuma alışkanlığının özellikle öğrencilerin anlama düzeylerine etki edeceği kanaati önceki sorulara vermiş olduğu cevaplarla tutarlı görülmektedir. Bununla birlikte okuma alışkanlığı kendine yakın olan muhakeme beceriler ve soru çözme alışkanlığını da etkilediği ifade edilmiştir. Öğretmenlerin bu tespiti literatüre de benzerlik göstermektedir (Kilpatrick, 2001). Ancak bunun kadar önemli bir diğer olgu matematik öğretmenlerinin öğrencilerin erken yaş veya sınıf dönemlerinde bir takım eğitimlere maruz bırakılmasının başarıyı ve öğrenci gelişimini artıracağı yönündedir. Bunlardan okuma alışkanlığı, veli sorumluluğu, soru çözme pratikleri gibi eğitimlerin öğrenci başarısını artırabileceği şeklindedir. Bununla ilişkili olarak şekil 1 incelendiğinde çeşitli döngülerin olduğu görülmektedir. Bu döngülerden biri erken dönem eğitimleri, okuma alışkanlığı, uygulamalı eğitim, kaynak kitap, müfredat döngüsü olduğu ve birbirini etkileyen bir süreç olduğu görülmektedir. Araştırmacılara açısından önemli görülen bir diğer döngünün okuma alışkanlığı, muhakeme, müfredat, soru 
çözme döngüsüdür. Bu döngünün öğrencilerde başarıyı etkileyebileceğini düşünmektedirler. Çünkü okuduğunu anlama ve ilişkilendirmenin her evresinde muhakemenin önem taşıdı̆̆

$\mathrm{Bu}$ araştırmada matematik öğretmenlerinin öğrenci başarısı üzerine belirttikleri görüşler dikkate alınarak ikinci döngü bir analize ihtiyaç duyulmuştur. Bu kodlama ve analiz şekil 2'de görüldüğ̈ gibidir. Buna göre öğrenci başarısında motivasyonun çok önemli bir etken olduğu söylenebilir. Her ne kadar motivasyonun öğrenme psikolojisi açısından başarı için tek başına yeterli olmadığı bilinse de (Howe, 2001) öğrenme sürecinde süreklilik açısından önemli bir etki yarattığı kabul edilmektedir. Bu yönüyle motivasyon bir diğer deyişle öğrenci istekliliği belirleyici rol oynadığı söylenebilir. Bazı öğretmenlerin bunu birinci döngü analizde ifade ettikleri şekilde öğrenci-aile ilişkisinin önemli rol oynadığı kanaati önemli kabul edilmiştir. Şekil 2'de görülen ve önemsenen bir diğer olgunun okuma ve ön yargı arasındaki ilişkidir. Burada görülen ilişki temelde zıt bir ilişkidir. Okuma alışkanlığı geliştikçe ön yargıda azalma ve dersi sevmenin ortaya çıkacağına yönelik bir inanç söz konusudur. Bu açıdan öğretmenlerin değerlendirmelerinde okuma alışkanlığının önemli bir yer tuttuğu ve bu alışkanlığın kazandırılmasının öğrencileri geleceğe hazırlama açısından önem taşıdığı söylenebilir.

\section{5. Öneriler}

Çalışmanın sonucunda ortaya çıkan verilerden hareketle, öğrencilerin yeni sınav sisteminde anlama, yorumlama, düşünme ve muhakeme etme gibi alana özgü becerilerde sorunu yaşadığı görülmektedir. Bununla birlikte ders kitapları ile sınavın paralel olmadığı bu nedenle öğretmenlerin çeşitli zorluklar yaşadığ1 görüşü ağırlıktadır. Bu doğrultuda öğrencilerin motivasyonun artırılması ve okuma alışkanlığının kazanılmasını sağlamak için çeşitli etkinlikler yapılabilir. Yapılandırmacı öğretim yöntem ve tekniklerinden faydalanarak öğrencilerin bilgileri inşaa edebilecekleri öğrenme ortamları tasarlanabilir ve buna yönelik çalışmalar yapılabilir. Ayrıca öğretmenlere de sınava yönelik hizmet içi eğitimlerinin verilmesinin yararlı olacağı düşünülmektedir.

\section{Kaynaklar / References}

Baki, A. (2008). Kuramdan uygulamaya matematik eğitimi. Ankara: Harf Eğitim Yayıncılığı

Başol, G., Balgalmış, E., Karlı, M. G., \& Öz, F. B. (2016) TEOG sınavı matematik sorularının MEB kazanımlarına, TIMSS seviyelerine ve yenilenen Bloom Taksonomisine göre incelenmesi. Journal of Human Sciences, 13(3), 5945-5967.

Breakwell, G. M., Wright, D. B., \& Smith, J. A. (2012). Research questions and planning research. Londra: SAGE Publications.

Businskas, A. M. (2008). Conversations about connections: How secondary mathematics teachers conceptualize and contend with mathematical connections (doctoral dissertation). Simon Fraser University, Canada.

Çepni, S.(2014). Araştırma ve proje çalışmalarına giriş (7.baskı). Trabzon: Celepler Matbaacılık

Francisco, J. M., \& Maher, C. A. (2005). Conditions for promoting reasoning in problem solving: Insights from a longitudinal study. Journal of Mathematical Behavior, 24, 361-372.

Generazzo, S. D. (2011). Proof and reasoning in an inquiry-oriented class: The impact of classroom discourse (doctoral dissertation) University of New Hampshire, New Hampshire.

Goswami U. (2004). Neuroscience and education. British Journal of Educational Psychology, 74, 1-14

Güven B., Öztürk T. ve Demir E. (2014, Eylül). Ortaöğretim matematik ögretmen adaylarının ispat sürecindeki muhakeme hatalarının incelenmesi. XI. Ulusal Fen ve Matematik Eğitimi Kongresi'nde sunulan bildiri, Çukurova Üniversitesi, Adana, Türkiye.

Güven B. ve Demir E. ( 2015, Mayıs). Öğrencilerin İspat Sürecinde Yaptıkları Muhakame Hatalarına Yönelik Öğretmen Bilgisinin Incelenmesi. 2. Türk Bilgisayar ve Matematik Eğitimi Sempozyumu'nda sunulan bildiri, Adıyaman Üniversitesi, Adıyaman, Türkiye.

Healy L., \& Hoyles C. (1998). Justifying and proving in school mathematics: Technical report on the nationwide survey. Institute of Education, University of London.

Hiebert, J., \& Grouws, D. A. (2007). The effects of classroom mathematics teaching on students' learning. In F. K. Lester (Ed.), Second handbook of research on mathematics teaching and learning ～(pp. 371-404). Charlotte, NC: Information Age Publishing.

Hsu, H. (2010). The study of Taiwanese students'experiences with geometric calculation with number (GCN) and their performance on GCN and geometric proof (doctoral dissertation,)The University of Michigan, Michigan.

Howe, K. R.(2001). Qualitative Educational Research: The Philosophical Issues. Wahington,DC: American Educational Research Association

İskenderoğlu, T. ve Baki, A. (2011). İlköğretim 8.sınıf matematik ders kitabındaki soruların PISA matematik yeterlik düzeylerine göre sinıflandırılması. Eğitim ve Bilim, 36(161), 287-301

Kilpatrick, J., Swafford, J., \& Findell, B. (2001). Adding It Up: Helping Children Learn Mathematics. Washington, DC: National Academy Press. 
Kinach, B. M. (2002). Understanding and learning-to-explain by representing mathematics: Epistemological dilemmas facing teacher educators in the secondary mathematics methods course. Journal of Mathematics Teacher Education, 5(2), 153186

Kumandaş, H., ve Kutlu, Ö. (2014). Yükseköğretime öğrenci seçmede ve yerleştirmede kullanılan sınavların oluşturduğu risk faktörlerinin okul başarısı üzerindeki etkileri. Türk Psikoloji Dergisi, $\quad$ 29(74), 15-31

McCrone, S. M. S. \& Martin, T. S. (2009). Formal Proof in High School Geometry: Student Perceptions of Structure, Validity, and Purpose. Teaching Proving by Coordinating Aspects of Proofs with Students' Abilities. In Stylianou, D. A.,. Blanton, M. L. \& Knuth, E.J. (Eds.), Teaching and Learning Proof Across Grades: A K-16 Perspective, (pp. 204-221). New York/Washington, DC: Routledge/National Council of Teachers of Mathematics.

Milli Eğitim Bakanlığı [MEB]. (2013). Ortaöğretim matematik dersi (9, 10, 11 ve 12. sinıflar) öğretim programı. Ankara: MEB Yayınları.

Milli Ĕ̆itim Bakanlığı [MEB]. (2018). Ortaöğretim matematik dersi (9, 10, 11 ve 12. sinıflar) öğretim programı. Ankara: MEB Yayınları.

National Council of Teachers of Mathematics [NCTM]. (2000). Principles and standards for school mathematics. Reston, VA: Author

Petrou, M. \& Goulding, M. (2011). Conceptualising teachers' mathematical knowledge in teaching. In T. Rowland \& K. Ruthven (Eds.), Mathematical Knowledge in Teaching, Mathematics Education Library 50 (pp. 9-25). London: Springer.

Pulley, C. A. (2010). Using instruction to investigate the effects of assessing reasoning tasks on students' understanding of proof (doctoral dissertation). Illinois State University, Illinois, USA.

Shulman, L. S. (1986). Those who understand: Knowledge growth in teaching. Educational Researcher, 67,4-14

Stylianides, A. J. and Stylianides, G. J. (2009). Proof constructions and evaluations. Educational Studies in Mathematics, 72, 237-253. doi: 10.1007/s10649-009-9191-3

Tiemann, G. E. (2011). The impact of a school-wide high school advanced placement program and culture on participating students' high school achievement and engagement outcomes and first year university academic success (doctoral dissertation). University of Nebraska, USA.

Vale, C., McAndrew, A., and Krishnan, S. (2011). Connecting with the horizon: Developing teachers' appreciation of mathematical structure. Journal of Mathematics Teacher Education, 14(3), 193-212.

Van de Walle, J. A. (2013). Elementary and middle school mathematics: Teaching developmentally (7th ed.). Boston: Allyn and Bacon. 